\title{
Physical property relationships of the Rotokawa Andesite, a significant geothermal reservoir rock in the Taupo Volcanic Zone, New Zealand
}

\author{
Paul A Siratovich ${ }^{1 *}$, Michael J Heap ${ }^{2}$, Marlène C Villenueve ${ }^{1}$, James W Cole ${ }^{1}$ and Thierry Reuschlé ${ }^{2}$
}

\author{
* Correspondence: \\ paul.siratovich@gmail.com \\ 'Department of Geological \\ Sciences, University of Canterbury, \\ Private Bag 4800, Christchurch 8140, \\ New Zealand \\ Full list of author information is \\ available at the end of the article
}

\begin{abstract}
Background: Geothermal systems are commonly hosted in highly altered and fractured rock. As a result, the relationships between physical properties such as strength and permeability can be complex. Understanding such properties can assist in the optimal utilization of geothermal reservoirs. To resolve this issue, detailed laboratory studies on core samples from active geothermal reservoirs are required. This study details the results of the physical property investigations on Rotokawa Andesite which hosts a significant geothermal reservoir.
\end{abstract}

Methods: We have characterized the microstructure (microfracture density), porosity, density, permeability, elastic wave velocities, and strength of core from the high-enthalpy Rotokawa Andesite geothermal reservoir under controlled laboratory conditions. We have built empirical relationships from our observations and also used a classical micromechanical model for brittle failure. Further, we compare our results to a Kozeny-Carman permeability model to better constrain the fluid flow behavior of the rocks.

Results: We show that the strength, porosity, elastic moduli, and permeability are greatly influenced by pre-existing fracture occurrence within the andesite. Increasing porosity (or microfracture density) correlates well to a decreasing uniaxial compressive strength, increasing permeability, and a decreasing compressional wave velocity.

Conclusions: Our results indicate that properties readily measurable by borehole geophysical logging (such as porosity and acoustic velocities) can be used to constrain more complex and pertinent properties such as strength and permeability. The relationships that we have provided can then be applied to further understand processes in the Rotokawa reservoir and other reservoirs worldwide.

Keywords: Geothermal; Uniaxial compressive strength; Permeability; Physical properties; Elastic modulus; Microstructure

\section{Background}

Fractures on multiple scales are the dominant control on fluid flow in most geothermal systems worldwide. Geothermal environments are prone to variable heat fluxes, dynamic fluid flow regimes, and active tectonics which impact the physical and mechanical properties of the reservoir rocks in which they are hosted. The influence of such a dynamic environment can render the host rocks highly altered, fractured, and microstructurally complex. As a result, the empirical correlation of physical properties to

\section{第 Springer}

(c) 2014 Siratovich et al.; licensee Springer. This is an Open Access article distributed under the terms of the Creative Commons Attribution License (http://creativecommons.org/licenses/by/4.0), which permits unrestricted use, distribution, and reproduction in any medium, provided the original work is properly cited. 
yield valuable relationships may not be entirely straightforward. Studies of these properties, and attempts to quantify how they relate to one another in the subsurface, can greatly assist in the optimization and maintenance of geothermal resources (e.g., Gupta and Sukanta 2006; DiPippo 2008; Grant and Bixley 2011).

Here, we detail the results of a systematic physical and mechanical property study on the Rotokawa Andesite; the major reservoir unit within the high-enthalpy Rotokawa Geothermal Field (Krupp and Seward 1987; Quinao et al. 2013), located within the Taupo Volcanic Zone (TVZ), North Island, New Zealand (Figure 1). We first examine the texture, mineralogy, petrology, and microstructure. The key physical properties are then explicitly investigated: porosity, density, elastic wave propagation and dynamic elastic moduli, uniaxial compressive strength, static elastic moduli, and permeability. We empirically correlate the microcrack density of the andesite to the measured physical properties. Further, we present empirical relationships of physical properties and classical micromechanical and geometrical models to predict both uniaxial compressive strength and permeability, respectively. Our data is discussed in relation to the Rotokawa Geothermal Field and their applicability to other geothermal resources worldwide.

\section{Previous studies of relevance}

The study of the core from geothermal systems can yield valuable information to assist their modeling and understanding. For example, Stimac et al. (2004) present a study

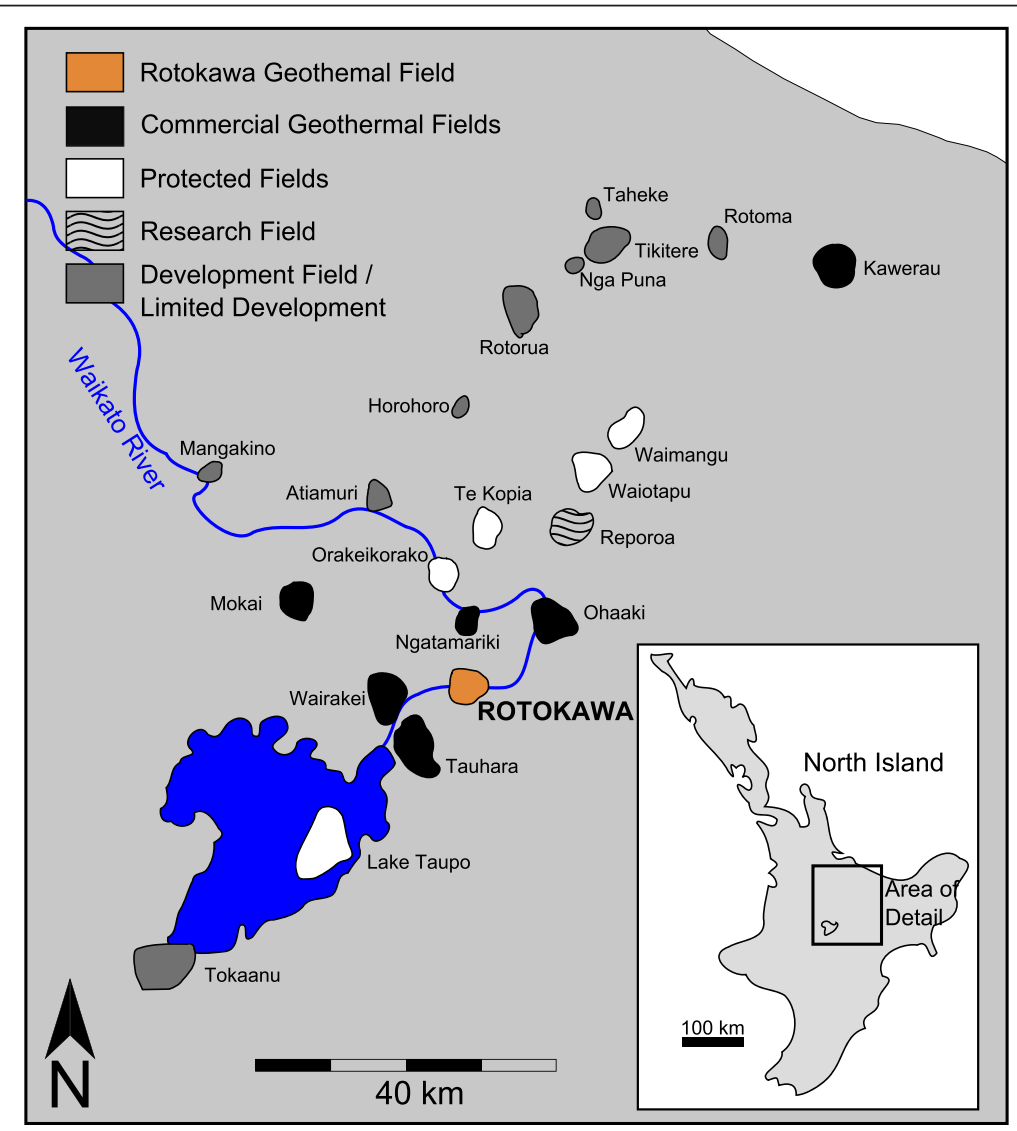

Figure 1 Geothermal fields of the Taupo Volcanic Zone (TVZ), North Island, New Zealand. Core used for this study was sourced from wells drilled in the Rotokawa Geothermal Field. (Adapted from Sewell et al. 2012). 
detailing the relationship between permeability and porosity from continuous core from Tiwi geothermal field, Philippines. Their data show that permeability and porosity decrease with depth, with occasional deviations attributed to alteration and compaction. However, the authors are careful to note that their work does not consider the influence of microfractures and their effect on relevant reservoir parameters. Lutz et al. (2010) present a case history of the well core from the Desert Peak field (NV, USA) in preparation for the stimulation of an enhanced geothermal system (EGS) by a thorough evaluation of petrological strength and elastic moduli. The results of their study elucidate relationships between clay mineralogy, rock fabric, and permeability increases as a result of mechanical shearing which support proposed hydraulic fracture operations in Well 27-15 at Desert Peak.

The effect of hydrothermal alteration on the physical properties of geothermal core is also a very significant area of research. Hydrothermal alteration can drastically change the elastic wave velocities and permeabilities of rock in both the natural and laboratory environment (Jaya et al. 2010; Kristinsdóttir et al. 2010; Pola et al. 2014). However, coupled studies of physical properties such as porosity, permeability, and strength on geothermal reservoir rocks have not been extensively presented. A detailed study of the impact of a complex microstructure (microfractures and hydrothermal alteration) on the rock physical properties of a geothermal system such as Rotokawa could serve to greatly improve the understanding of reservoir processes at multiple scales.

Geothermal systems are more often than not associated with volcanic systems and are often hosted in rocks sourced from extinct volcanic systems. By proxy, the study of rocks from volcanic edifices can help to boost the understanding of processes within geothermal reservoirs especially with regard to microfractures, which play an essential role in controlling strength, porosity, permeability, elastic wave velocities, and elastic moduli of rocks (Wu et al. 2000; Guéguen and Schubnel 2003; Pereira and Arson 2013; Faoro et al. 2013; Pola et al. 2014; Heap et al. 2014). For example, Vinciguerra et al. (2005) studied the influence of thermal stressing on basaltic samples. They show, using elastic wave velocities, that the response of microstructurally variable basalts to thermal stressing can be quite different. While fresh microlitic basalt exhibited severe reductions in P-wave velocity after exposure to $900^{\circ} \mathrm{C}$, the P-wave velocity of porphyritic basalt with a pervasive microcrack network did not change.

Similar dependence on the effect of microfractures on strength (Smith et al. 2009) and permeability (Nara et al. 2011) has been investigated, with microfractures proving to be deleterious to strength and to enhance permeability. Heap et al. (2014) showed, for a suite of pervasively fractured andesites, that an increase in porosity from 8 to 29 vol\% decreases strength by a factor of 8 and increases permeability by 4 orders of magnitude. David et al. (1999) showed that mechanical and thermal microcracking in granites results in significant changes to permeability and elastic wave velocities. Mechanical microcracking resulted in the development of P-wave velocity anisotropy, while thermally microcracked samples showed little P-wave anisotropy. Additionally, permeability was much more varied in mechanically microcracked rocks than those induced thermally, suggesting that thermal microcracks develop isotropically. Chaki et al. (2008) investigated the role of thermal microcracking in granites and showed that elastic wave propagation is attenuated by microcracks and the orientation of these thermal microcracks (with regard to the original microstructure) plays a critical role in the 
propagation and attenuation of the waves. Faoro et al. (2013) provide a model for how microcrack density within an isotropically microcracked sample can be modeled as a function of aspect ratio and microcrack connectivity. Elastic moduli and elastic wave velocities are strongly influenced by the morphology, distribution, and shape of pore space in rocks and are substantially attenuated by the presence of microcracks (Stanchits et al. 2006 and references therein).

The relationship between porosity and strength has been observed by many authors, with general agreement that as the porosity of a sample (both rock and other engineering materials) increases, the strength decreases (e.g., Al-Harthi et al. 1999; $\mathrm{Li}$ and Aubertin 2003; Kahraman et al. 2005; Chang et al. 2006; Diamantis et al. 2009; Ju et al. 2013; Baud et al. 2014; Heap et al. 2014). The geometry of the pores also has a significant role in the strength of the materials both intrinsically and with respect to the direction of stress (Luping 1986). The microstructure of rocks can be changed by increasing the crack damage (by mechanical and/or thermal stresses) as well as hydrothermal alteration (Heap et al. 2009; Nara et al. 2011; Pola et al. 2014); these changes can be observed through the evaluation of destructive and nondestructive physical property measurements (Pola et al. 2012 and references therein; Sousa et al. 2005). Further, Pola et al. (2014) also show that hydrothermal alteration of volcanic rocks can either strengthen or weaken rocks by decreasing or increasing their porosity, respectively.

\section{Geological significance of the Rotokawa Andesite}

The TVZ is a rifted arc associated with the Hikurangi subduction system in which the Pacific plate descends beneath the Australasian plate (Cole 1990; Wilson et al. 1995), and hosts active volcanism and multiple associated hydrothermal systems (Bibby et al. 1995; Rowland and Sibson 2004; Rowland et al. 2010). The Rotokawa field is one of these active hydrothermal systems and has been the subject of exploration for mineral resources (sulfur and gold deposits) and, for many years, was the subject of detailed investigation into its use as a commercial geothermal resource (Collar and Browne 1985; Krupp and Seward 1987; Hedenquist et al. 1988). More recently, electricity generation has been realized at Rotokawa following the installations of the Rotokawa I (1997) and Nga Awa Purua (2010) generation stations (Legmann and Sullivan 2003; Bloomberg et al. 2012). The more recent of these installations, the Nga Awa Purua power station, hosts the single largest geothermal turbine installation in the world and has a generation capacity $>140$ MWe which is approximately $3 \%$ of New Zealand's electricity consumption (Horie and Muto 2010).

The main production zone for the installations at Rotokawa is from that of the Rotokawa Andesite, a series of lavas, pseudo-breccias, and breccias. The movement of fluid through the andesite is predominantly along fracture networks (Rae 2007; Massiot et al. 2012). The andesite overlies basement of Miocene greywacke and is capped by a sequence of volcaniclastic and sedimentary units: Reporoa Group, Wairakei Ignimbrite, Waiora Formation, and Huka Falls Formation (Krupp and Seward 1987; Rae 2007). The andesite is gray to green and occasionally purple in color, depending on alteration within the reservoir; alteration is less intense in the lavas and more intense in the breccia and pseudo-breccia (Ramirez and Hitchcock 2010). Production of reservoir fluids is sourced from the Rotokawa Andesite by 12 wells in the central part of the field 
(Figure 2), and re-injection of spent fluids is done through 5 wells along the southeastern margin of the field (Powell 2011).

\section{Methods}

\section{Study source material}

The samples used in this study were sourced from Rotokawa production wells RK27L2, RK28, and RK30 (Figure 2). The measured depths (total borehole length measured from drilling rig floor), orientations, and corrected true vertical depths (TVD) are listed in Table 1 . The original cores were approximately $6-\mathrm{m}$ long and 100-mm diameter, and were initially described by the GNS Science Wairakei Research Centre, New Zealand, in a series of internal industry reports detailing the respective production wells from surface to total depth (TD). These reports describe the stratigraphic sequences of the wells and rock types, hydrothermal alteration, and locations of the wells (Rae et al. 2009; Rae et al. 2010; Ramirez and Hitchcock 2010).

At the University of Canterbury (UC), the cores were catalogued and cut into workable cylinders approximately $100 \mathrm{~mm}$ in length. These smaller sections were over-cored to obtain smaller cylindrical samples $40 \mathrm{~mm}$ in diameter and ranging from 80 to $100 \mathrm{~mm}$ in length. All samples were machined so that their end faces were flat and parallel in accordance with ISRM standards (Ulusay and Hudson 2007).

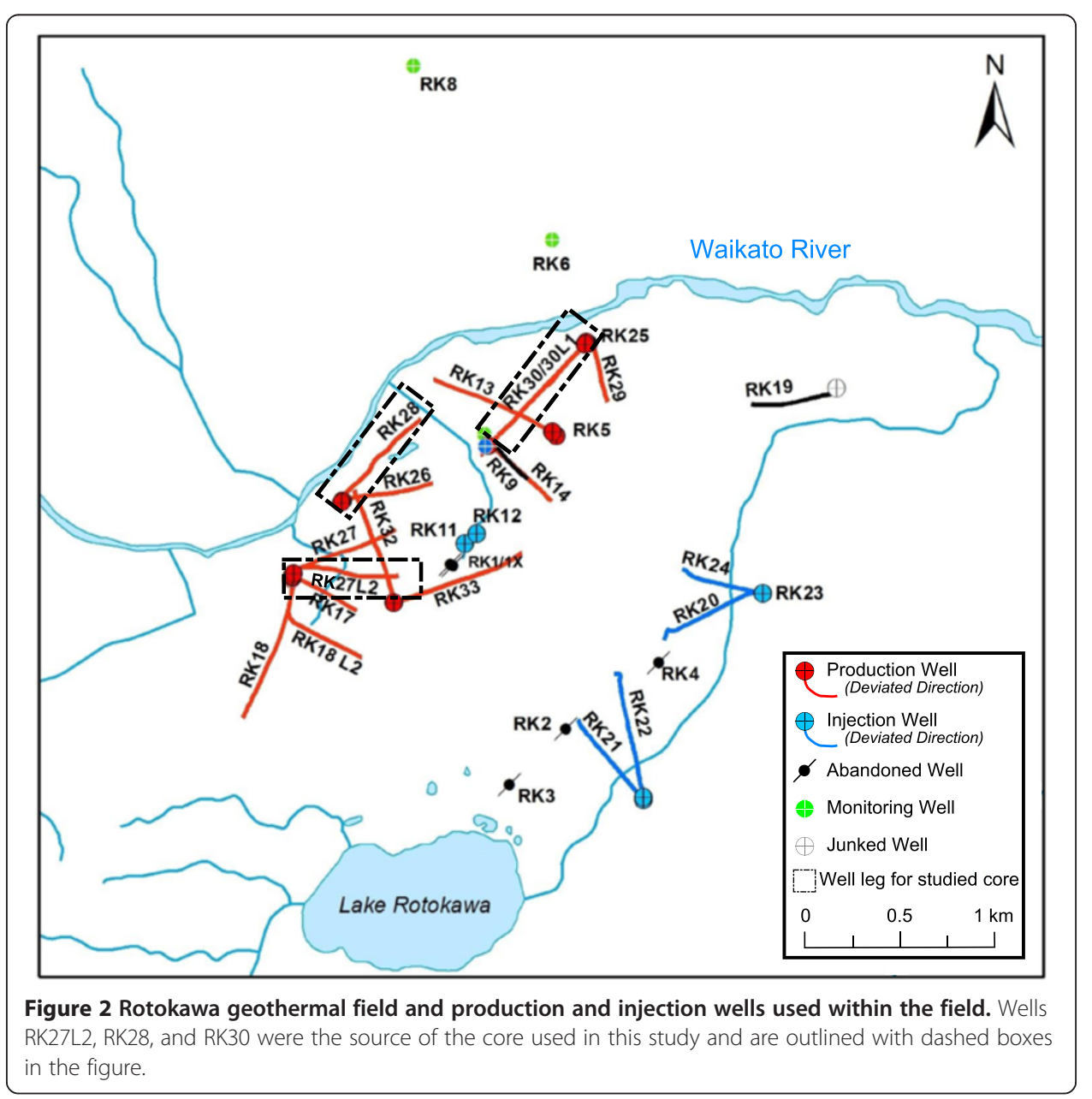


Table 1 Detail of core retrieval points from within the Rotokawa Andesite reservoir

\begin{tabular}{lllll}
\hline Well name & $\begin{array}{l}\text { Measured depth } \\
\text { of core points }(\mathbf{m})\end{array}$ & $\begin{array}{l}\text { True vertical depth } \\
\text { (meters below reference level) }\end{array}$ & $\begin{array}{l}\text { Inclination from } \\
\text { vertical (degrees) }\end{array}$ & $\begin{array}{l}\text { Azimuth from } \\
\text { north (degrees) }\end{array}$ \\
\hline RK28 ST1 & 2,310 to 2,316 & $-2,215$ to 2,221 & 21.94 & 50.91 \\
RK27 L2 & 2,120 to 2,126 & $-2,001$ to 2,007 & 27.31 & 88.11 \\
RK30 L1 & 2,320 to 2,326 & $-2,175$ to 2,182 & 20.11 & 218.47 \\
\hline
\end{tabular}

Measured depths are given as measured from the elevation of the drilling rig floor, true vertical depths are corrected to subsurface elevations, inclination is the deviation from vertical, and azimuth is the orientation of the borehole trajectory.

\section{Microstructural characterization}

The strength, porosity, permeability, and acoustic velocities can be significantly influenced by the presence of microfractures in a sample. Therefore, we deemed it necessary to develop a fundamental understanding of the microfracture densities in the samples. In order to characterize these features, 10 polished thin sections were prepared from offcuts of the cylinders used for the property characterization described below. The thin sections were prepared perpendicular to the core axis ( $X-Y$ plane) and, using reflected light thin section photomicrography (at $\times 40$ magnification), were examined for microfracture densities using the methods suggested by Underwood (1970) and further described by Richter and Simmons (1977), Wu et al. (2000), and Heap et al. (2014). In each thin section, an $11 \times 11 \mathrm{~mm}^{2}$ area was selected, which was subdivided into sections of $1 \times 1 \mathrm{~mm}^{2}$. The number of cracks that intersected a grid array of parallel and perpendicular lines that were spaced at $0.1 \mathrm{~mm}$ was counted. This allowed the calculation of the crack surface area per unit volume according to Equation 1 (Underwood 1970):

$$
\mathrm{Sv}=\pi / 2 P_{1}+(2-\pi / 2) P_{11}
$$

where $\mathrm{Sv}$ is the crack surface area per unit volume (in $\mathrm{mm}^{2} / \mathrm{mm}^{3}$ ), $P_{1}$ is the number of perpendicular lines crossed by crack intersections, and $P_{\mathrm{ll}}$ is the number of parallel lines crossed by crack intersections. We also characterized the anisotropy of microfracture distribution using Equation 2 (Underwood 1970):

$$
\Omega_{23}=P_{1}-P_{11} / P_{1}+(4 / \pi-1) P_{11}
$$

\section{Density and porosity measurements}

Once the samples were cut and ground flat and parallel, they were washed with water to remove any debris from sample preparation. They were then immersed in distilled water under vacuum of about $100 \mathrm{kPa}$ for $24 \mathrm{~h}$. Samples were taken out of the water and were weighed after their surface water had been removed. The samples were then placed into a laboratory oven at $105^{\circ} \mathrm{C}$ and dried until a constant mass was observed. Subsequently, they were removed from the oven and held in a dessicator until further characterization was implemented. Sample lengths and diameters were measured to within $0.01 \mathrm{~mm}$. The connected porosity and dry bulk density of the samples were calculated following the methods recommended by Ulusay and Hudson (2007).

\section{Characterization of elastic wave velocities and dynamic elastic moduli}

The compressional wave ( $\mathrm{Vp})$ and shear wave (Vs) velocities and dynamic elastic moduli were measured using a GCTS (Geotechnical Consulting and Testing Systems, 
Tempe, AZ, USA) Computer Aided Ultrasonic Velocity Testing System (CATS ULT-100) apparatus with axial $\mathrm{P}$ - and $\mathrm{S}$-wave piezoelectric transducers (Figure 3). The resonance frequency of the transducers was $900 \mathrm{kHz}$, pulse acquisition rate was $20 \mathrm{MHz}$, and 108 waveforms were captured for each sample. The velocities were collected under a constant uniaxial stress of $10 \mathrm{MPa}$ via a Tecnotest servo-controlled 3,000 kN loading frame (Technotest, Modena, Italy) (Figure 3). The stress of $10 \mathrm{MPa}$ was used to ensure a consistent waveform across the specimens and that applied stress was consistent for all measurement cycles. This was determined to be below microcrack closure and opening stress by analyzing the change in axial strain as the sample was loaded to $10 \mathrm{MPa}$ (Eberhardt et al. 1998). There was no change in axial strain and absence of acoustic emissions (AEs) during the initial loading (Brace et al. 1966; Martin and Chandler 1994; Lion et al. 2005; Nicksiar and Martin 2012); this ensured a good quality interpretation of the first arrival time of elastic wave pulses. Using these data, we determined the dynamic Poisson's ratio and Young's modulus using Equations 3 and 4 (Guéguen and Palciauskas 1994), respectively:

$$
\begin{aligned}
& V_{\mathrm{d}}=\left(\mathrm{Vp}^{2}-2 \mathrm{Vs}^{2}\right) / 2\left(\mathrm{Vp}^{2}-\mathrm{Vs}^{2}\right) \\
& E_{\mathrm{d}}=\left(\rho \mathrm{Vs}^{2}\left(3 \mathrm{Vp}^{2}-4 \mathrm{Vs}^{2}\right)\right) /\left(\mathrm{Vp}^{2}-\mathrm{Vs}^{2}\right)
\end{aligned}
$$

Where $\mathrm{Vp}$ is compressional wave velocity in meters per second, Vs is shear wave velocity in meters per second, $E_{\mathrm{d}}$ is the dynamic Young's modulus in pascal, $V_{\mathrm{d}}$ is the dynamic Poisson's ratio, and $\rho$ is density in kilograms per cubic meter. Our physical

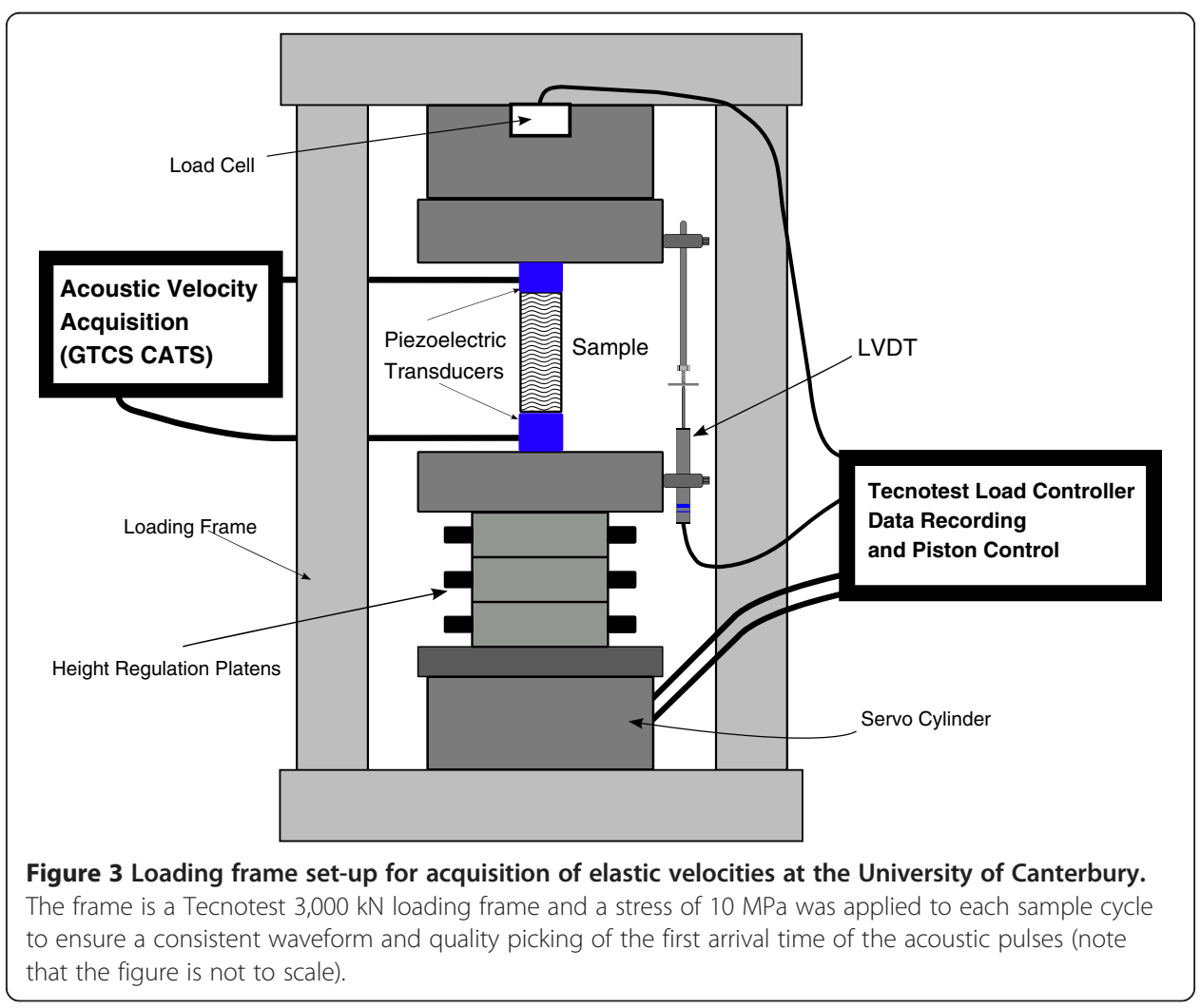


property characterizations are summarized in Table 2 . In addition to the determination of the elastic moduli from our elastic wave velocity measurements, we also utilized the method of Martínez-Martínez et al. (2011) to characterize the spatial attenuation of the compressional waveform anisotropy (Equation 5):

$$
\alpha_{\mathrm{s}}=20 \log \left(A_{\mathrm{e}} / A_{\max }\right) / L
$$

where $\alpha_{\mathrm{s}}$ is spatial attenuation in decibels per centimeter, $A_{\mathrm{e}}$ is the maximum amplitude emitted by the piezoelectric crystal, $A_{\max }$ is the recorded maximum amplitude of the pulse after passing through the sample, and $L$ is the length of the sample in meters.

\section{Uniaxial compressive strength testing and static elastic moduli}

Uniaxial compressive strength (UCS) was determined using a Technotest 3,000 kN, servo-controlled loading frame (Figure 4). Four strain gauges (20-mm strain gauges with a gauge factor of 2.12 supplied by Tokyo Sokki Kenkyujo Co. Ltd. (TML) Shinagawa-ku, Tokyo, Japan) were glued onto each sample. Two vertical gauges measured axial strain and two laterally oriented gauges measured radial strain; care was taken to ensure that the strain gauges were perpendicular to their respective axes of deformation. The specimens were deformed at a constant strain rate of $1.0 \times 10^{-5} \mathrm{~s}^{-1}$ (controlled by linear variable differential transformer, LVDT) at ambient laboratory temperature and humidity conditions. During experimentation, AE output was monitored using Physical Acoustics Corporation MISTRAS' AE node acquisition system (Princeton Jct, NJ, USA). Two physical acoustics WS $\alpha$ AE transducers (100 to $900 \mathrm{kHz}$ operating frequency) were attached to the samples at the top and base, and hit counts, waveforms, energy, and amplitude of the received signals were recorded during sample deformation. AE monitoring was used during deformation as a proxy for microcracking as AEs are generated by the release of energy from a material during the propagation and nucleation of microcracks (Eberhardt et al. 1998; Diederichs et al. 2004). We utilized arbitrary AE energy units (the area under the received waveform signal) for comparison of $\mathrm{AE}$ activity across the datasets. Once stress-strain curves were obtained and $\mathrm{AE}$ data are processed, we calculated the static elastic moduli for each specimen

Table 2 Results of quantitative microstructural characterization

\begin{tabular}{|c|c|c|c|c|c|}
\hline Sample name & $\begin{array}{l}\text { Crack density for } \\
\text { intercepts parallel } \\
\text { to orientation axis } \\
P \|\left(\mathrm{mm}^{-1}\right)\end{array}$ & $\begin{array}{l}\text { Crack density for } \\
\text { intercepts perpendicular } \\
\text { to orientation axis } \\
P \mid\left(\mathrm{mm}^{-1}\right)\end{array}$ & $\begin{array}{l}\text { Crack area per } \\
\text { unit volume } \\
\text { Sv }\left(\mathrm{mm}^{2} / \mathrm{mm}^{3}\right)\end{array}$ & $\begin{array}{l}\text { Anisotropy } \\
\text { factor } \Omega_{2,3}\end{array}$ & $\begin{array}{l}\text { Connected } \\
\text { porosity } \\
\text { (vol\%) }\end{array}$ \\
\hline 27_21_OB & 13.73 & 13.53 & 13.06 & 0.01 & 14.91 \\
\hline 28_10_5A & 4.10 & 4.41 & 8.33 & 0.06 & 7.47 \\
\hline 27_20_4_B & 1.83 & 2.06 & 3.77 & 0.08 & 4.37 \\
\hline 27_3_3B & 4.77 & 4.77 & 9.55 & 0.01 & 9.81 \\
\hline 30_22_4A & 2.77 & 2.62 & 5.48 & 0.01 & 6.49 \\
\hline 28_10_9B & 3.84 & 3.90 & 7.71 & 0.03 & 7.42 \\
\hline 28_12_1 & 4.83 & 4.65 & 9.59 & 0.02 & 7.89 \\
\hline 30_21_1B & 2.93 & 2.91 & 5.85 & 0.01 & 7.47 \\
\hline 27_21_3A & 5.80 & 5.13 & 11.31 & 0.09 & 16.3 \\
\hline 28_10_6C & 2.97 & 2.87 & 6.38 & 0.05 & 5.97 \\
\hline
\end{tabular}

As discussed in the section on microstructural characterization, crack densities were calculated on thin section samples to ascertain crack areas per unit volume using the optical microscope method (Underwood 1970). 


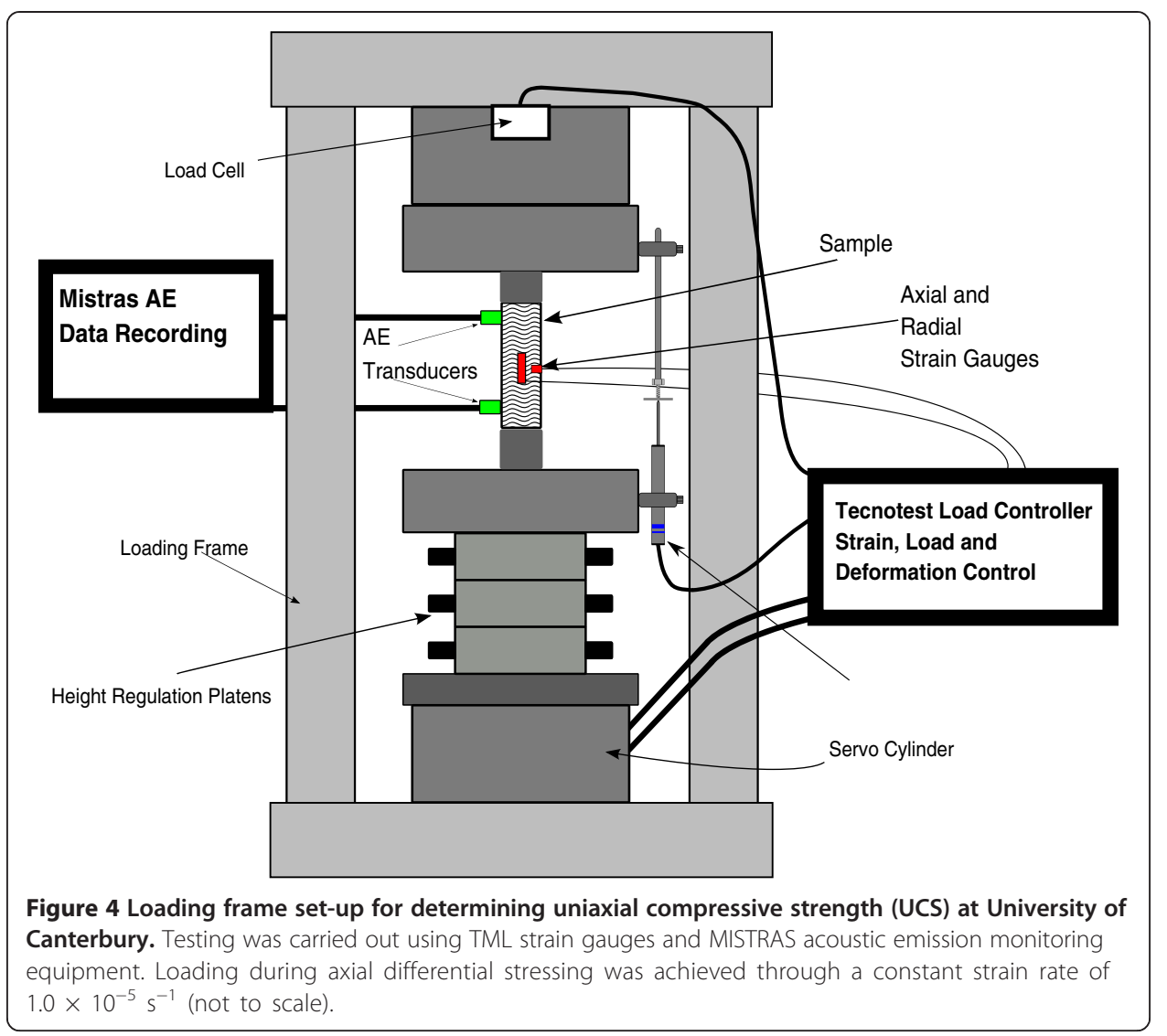

utilizing Equations 6 and 7 with the tangent deformation modulus at $50 \%$ of the maximum peak stress (Ulusay and Hudson 2007). In addition, we selected portions of the stress-strain sequence to identify crack closure, crack initiation, unstable crack propagation, and, ultimately, crack coalescence and sample failure (Martin 1993; Eberhardt et al. 1998; Takarli et al. 2008; Heap and Faulkner 2008):

$$
\begin{aligned}
& E_{\mathrm{s}}=(\Delta \sigma \mathrm{a} / \Delta \varepsilon \mathrm{a}) \\
& v_{\mathrm{s}}=-(\Delta \varepsilon \mathrm{r} / \Delta \varepsilon \mathrm{a})
\end{aligned}
$$

where $E_{\mathrm{s}}$ is the static Young's modulus $(\mathrm{Pa}), v_{\mathrm{s}}$ is the static Poisson's Ratio, $\sigma \mathrm{a}$ is the differential axial stress $(\mathrm{Pa}), \varepsilon \mathrm{a}$ is the axial strain, and $\varepsilon r$ is the radial strain.

\section{Permeability measurements}

Gas (argon) permeability measurements were made at the Laboratoire de Déformation des Roches, Université de Strasbourg (France). The 40-mm diameter specimens were over-cored to a diameter of $20 \mathrm{~mm}$ and cut and ground flat and parallel to a nominal length of $40 \mathrm{~mm}$. The new samples were then re-evaluated by the triple-weight method to obtain porosity via the Archimedes' method (Ulusay and Hudson 2007) and ovendried under vacuum at $40^{\circ} \mathrm{C}$ until no change in sample mass was observed. The samples were then jacketed with viton sleeves, placed between two steel end-caps and lowered into the pressure vessel (Figure 5). A confining pressure of $2 \mathrm{MPa}$ was applied to the sample (provided by distilled water), and permeability measured using the transient method (or pulse-decay method). For the permeability measurements, an initial differential pore 


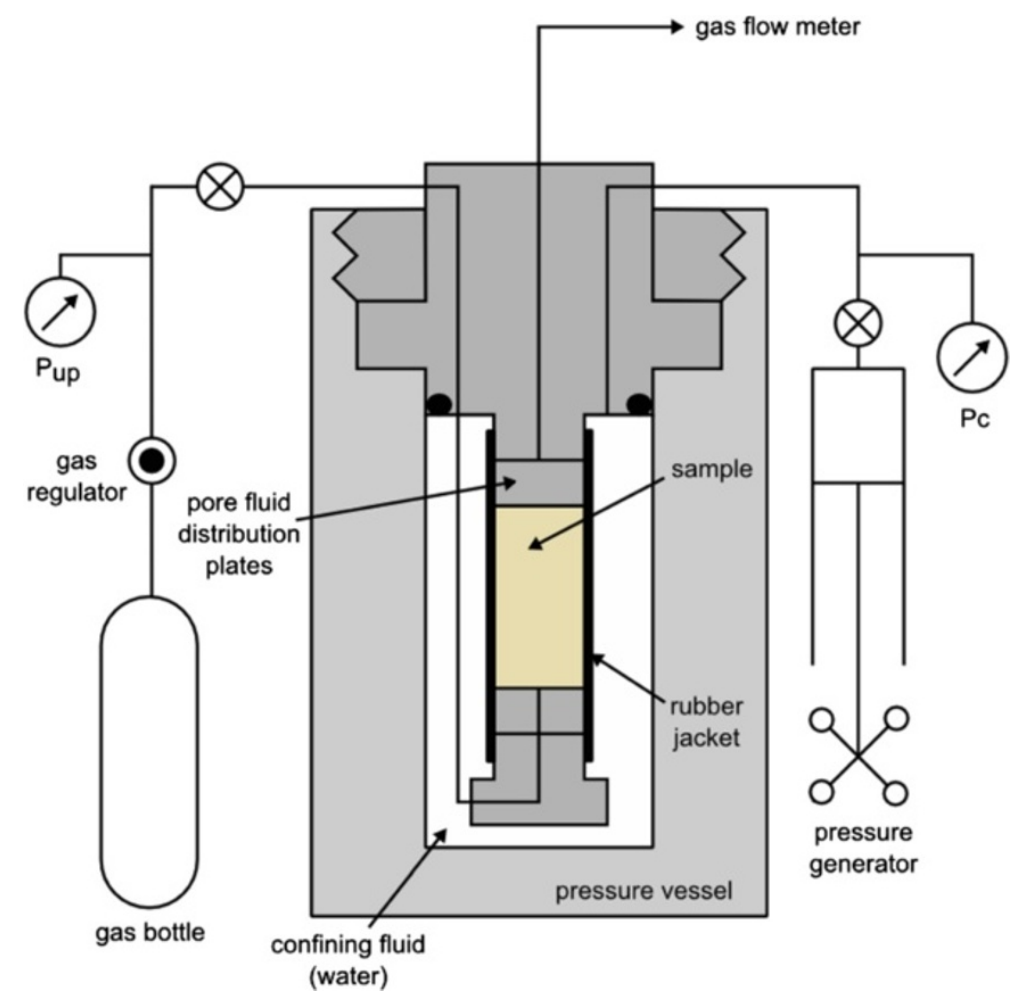

Figure $\mathbf{5}$ Gas permeameter used to measure permeability at University of Strasbourg (not to scale). Confining pressure of $2 \mathrm{MPa}$ was applied using distilled water as the pressurizing media, and pore fluid was dry argon gas supplied at $1.5 \mathrm{MPa}$ for a net effective pressure of $0.5 \mathrm{MPa}$.

pressure was applied to the sample, the upstream inlet was then closed, and the pore pressure decay monitored over time. The downstream fluid pressure $\left(P_{\text {down }}\right)$ was the ambient atmospheric pressure, and the maximum upstream fluid pressure $\left(P_{\text {up }}\right)$ was set so the pressure differential was $0.5 \mathrm{MPa}$. Permeability was then calculated using Equation 8 (after Brace et al. 1968):

$$
k_{\text {gas }}=(2 \eta L / A)\left(V_{\text {up }} /\left(P_{\text {up }}\right)^{2}-\left(P_{\text {down }}\right)^{2}\right)\left(\Delta P_{\text {up }} / \Delta t\right)
$$

where $k_{\text {gas }}$ is the gas permeability, $\eta$ is the viscosity of the pore fluid, $A$ is the crosssectional area of the sample, $V_{\text {up }}$ is the volume of the upstream pore pressure circuit (approximately $7 \mathrm{~cm}^{3}$ ), $P_{\text {up }}$ is the upstream pore pressure, $P_{\text {down }}$ is the downstream pore pressure, and $t$ is the time. By plotting $\Delta P_{\text {up }}$ as a function of time, the local slope of the curve is computed to determine the temporal variation of the permeability $k_{\text {gas. }}$. To check whether our data should be corrected for Klinkenberg's 'slip flow' (Klinkenberg 1941), we plotted the measured gas permeability as a function of the inverse of the mean pore fluid pressure, $P_{\text {mean }}$. For the transient method, since $P_{\text {down }}$ is constant, the decay of $P_{\text {up }}$ through time corresponds to the decay of the mean pore pressure $P_{\text {mean }}$. We found that, in all cases, the Klinkenberg correction should be applied:

$$
k_{\text {true }}=k_{\text {gas }}\left(1+b / P_{\text {mean }}\right)
$$

where $k_{\text {true }}$ is the true gas permeability, $b$ is Klinkenberg slip factor, and $P_{\text {mean }}$ is the mean pore fluid pressure. 


\section{Results}

In the following section, we present our data and observations on petrology, microstructure (quantitative microfracture analysis), macrostructure (bulk density, porosity, acoustic wave velocities, and dynamic moduli), strength relations (by UCS testing), and finally the ability of the rock to transmit fluid (permeability) of the Rotokawa Andesite.

\section{Petrology}

The Rotokawa Andesite shows moderate to intense hydrothermal alteration with the groundmass and phenocrysts showing replacement of original mineralogy. Fractures and occasional veins of quartz, calcite, anhydrite, and epidote occur, and amygdales within the sample are often filled with chlorite, calcite, hematite, pyrite, and chalcedony, often with quartz rims (Figure 6). Alteration is pervasive with the original mineral assemblages typically replaced by secondary hydrothermal alteration species, with some specimens showing very little original mineralogical texture. Plagioclase feldspars have been altered to albite, adularia, occasional calcite, and rare pyrite, and ferromagnesian minerals have been replaced by chlorite, quartz, calcite, and occasional epidote. Microfractured phenocrysts (Figures 6 and 7) are abundant and many relict phenocrysts retain original texture are but replaced by secondary mineralization. The average phenocryst size is 0.5 to $1 \mathrm{~mm}$ with occasional plagioclase near 1.5 to $2 \mathrm{~mm}$; amygdales also range from 1 to $1.5 \mathrm{~mm}$ in size. The alteration chemistry of the samples indicates that this portion of the reservoir is dominated by chlorite/epidote alteration. The degree of alteration is relatively consistent across the core we have sampled with most primary mineralogies replaced by secondary alteration products. Microfracture mineralization indicates that these networks may have been conductive pathways for fluid migration (i.e., the presence of chlorite clays, adularization of plagioclase, calcite, and quartz rimming of fractured matrix); we typically observe chlorite, calcite, and quartz as alteration mineralogies with occasional epidote centers within the fractures. Backscatter scanning electron microscopy (SEM) was utilized to further reiterate the complex interaction of fractures and vesicles in the specimens (Figure 7). At several different magnifications, we see an abundance of microfractures in the samples as well as a clear depiction of the complex alteration mineralogy displayed by the andesite.

\section{Quantitative two-dimensional microstructural analysis}

We evaluated the microfracture density of 10 specimens as a function of crack surface area per unit volume (Table 2). These samples were selected to represent the range of connected porosities observed within the sample set. We found that the crack area per unit volume in our samples ranges from 3.77 to $13.06 \mathrm{~mm}^{2} / \mathrm{mm}^{3}$ and appears to be independent of the alteration and mineralogy of the specimens. The calculated anisotropy factor $\left(\Omega_{2,3}\right)$, indicates that the microcracks are isotropic (Table 2).

\section{Porosity and bulk density}

Bulk density decreases as connected porosity increases, as expected for samples of similar composition (Figure 8A). Bulk dry densities of the samples range from 2.29 to $2.65 \mathrm{~g} / \mathrm{cm}^{3}$, with a mean value of $2.49 \mathrm{~g} / \mathrm{cm}^{3}$. The connected porosities range from 4.37 to $16.3 \mathrm{vol} \%$, with a mean value of $8.44 \mathrm{vol} \%$. While there is some variation in the distribution of pores/vesicles in the samples, we observe that the microcrack density 

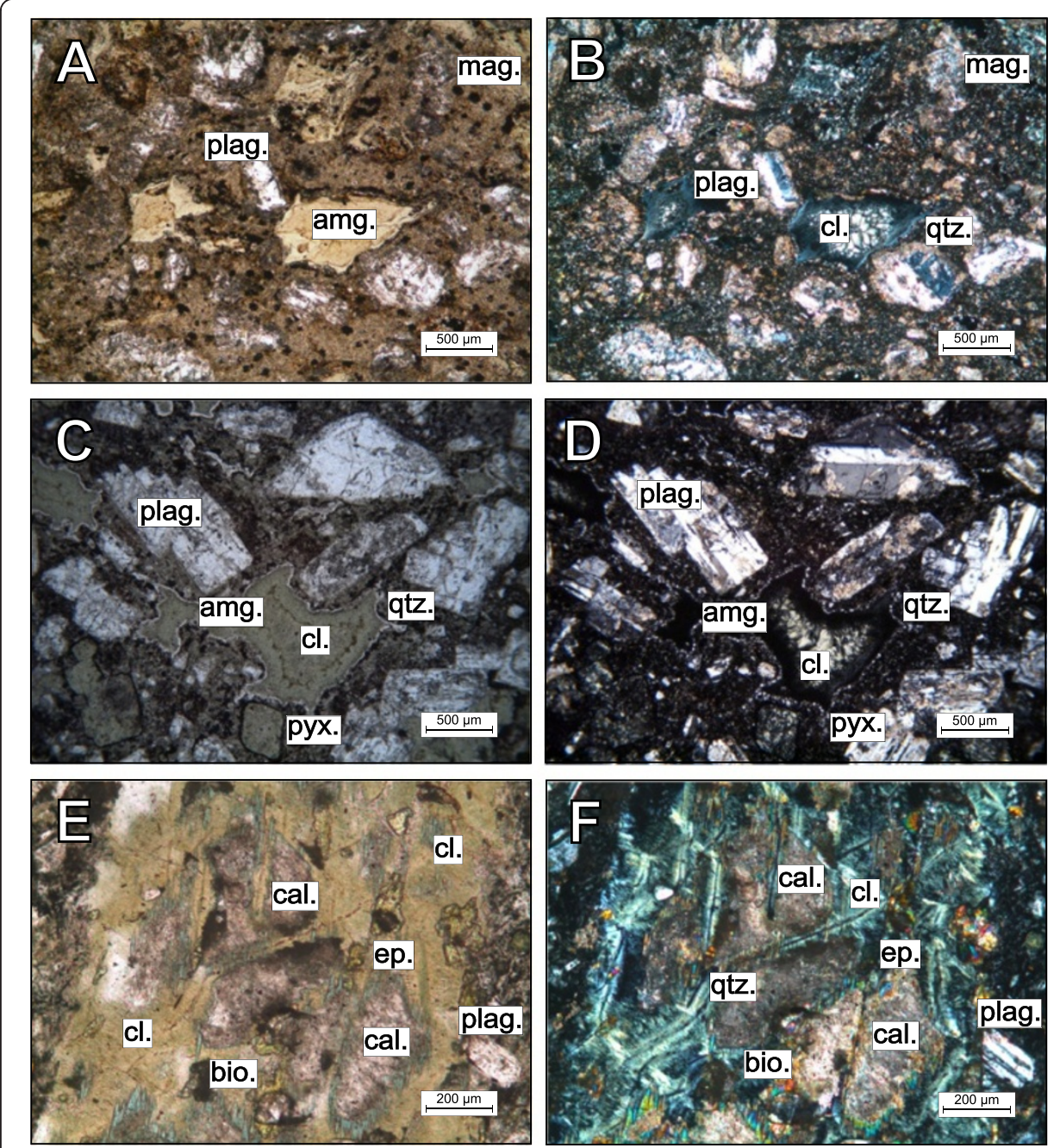

Figure 6 Thin section photomicrographs of the Rotokawa Andesite. (A) Plane-polarized light of RK28 2310.6C andesitic pseudo-breccia with plagioclase laths (plag.), groundmass is altered plagioclase, abundant magnetite (mag.), and amygdale (amg.). (B) Cross-polarized light of RK28 2310.6C clearly shows alteration fabrics of the brecciated andesite with plagioclase (plag.) and amygdales filled with chlorite (cl.) and rimmed by quartz (qtz.). (C) Plane-polarized light view of RK27_L2 2121.4A showing andesitic breccia with plagioclase with slight adularia alteration (plag.) and amygdale (amg.) filled with chlorite (cl.), quartz (qtz.), and highly altered pyroxene (pyx.) in lower portion of image. (D) Cross-polarized light view of RK27_L2 2121.4A shows chlorite infill of a large amygdale (amg.) in the center of the photomicrograph and quartz rim (qtz.), plagioclase (plag.), and highly altered pyroxene (pyx.). (E) Plane-polarized light view of RK30 2322.4A shows highly altered and microfractured plagioclase phenocryst with intense alteration and replacement by chlorite (cl.), epidote (ep.), calcite (cal), possible biotite (bio.), and small plagioclase showing evidence of adularia alteration (plag.). (F) Cross-polarized light of RK30 2322.4A illustrates microfracture network and veining with alteration products of quartz (qtz.), epidote (ep.), biotite (bio.), calcite (cal.), and plagioclase (plag.).

exerts an important control on the porosity and density, as illustrated by the correlation between crack area per unit volume and connected porosity presented as Figure $8 \mathrm{~B}$.

\section{Ultrasonic wave velocities, dynamic elastic moduli, and spatial attenuation}

Measurements made on dry samples under ambient (pressure and temperature) conditions yielded axial P-wave velocities from 3,627 to $4,556 \mathrm{~m} / \mathrm{s}$ with a mean value of $4,106 \mathrm{~m} / \mathrm{s}$, and axial S-wave velocities between 2,160 to $2,752 \mathrm{~m} / \mathrm{s}$ with a mean value of 


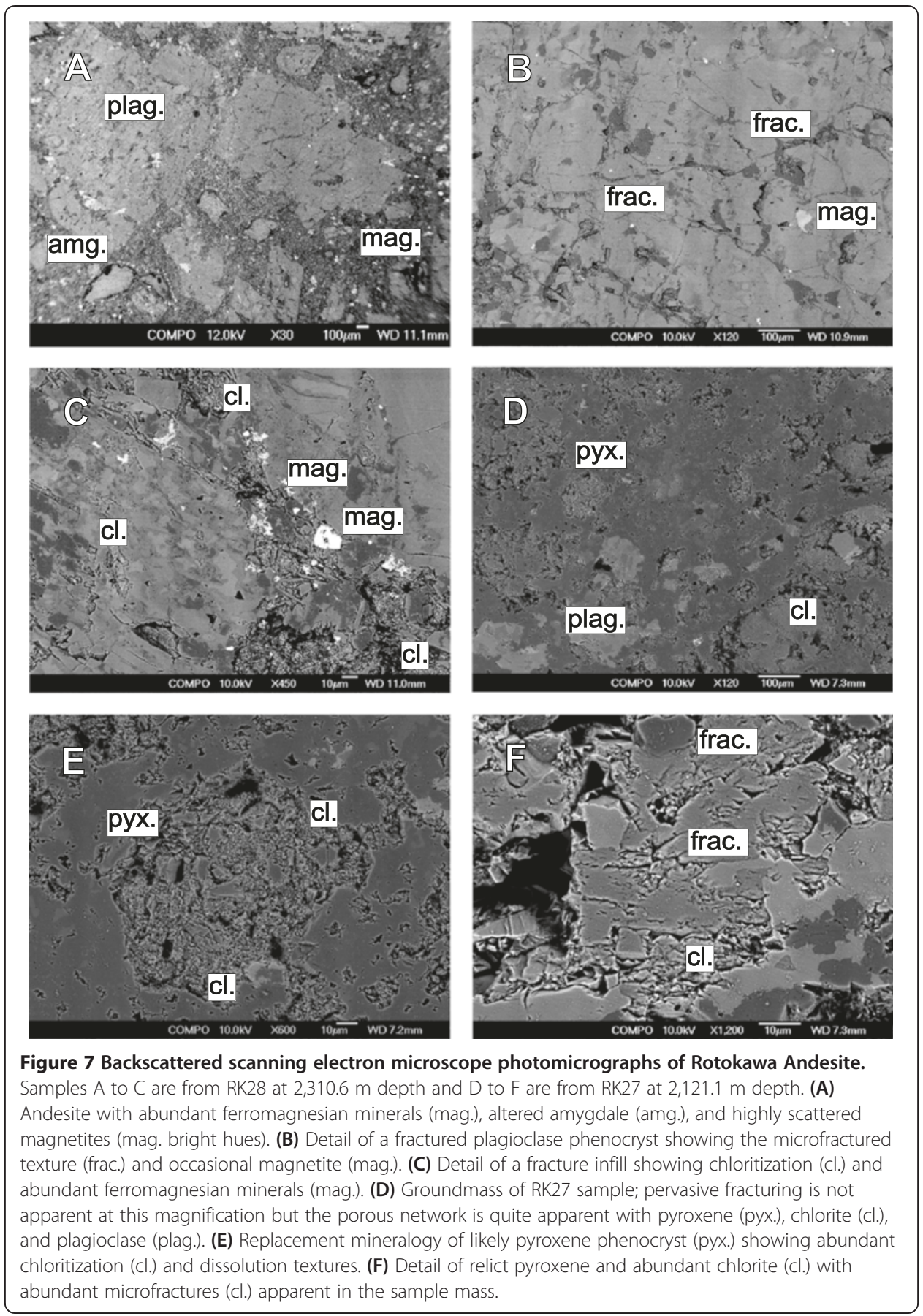

2,510 m/s (Table 3). Porosity and P-wave velocities show moderate correlation: samples with higher porosities have slower elastic wave velocities, as seen in Figure $8 \mathrm{C}$. The crack area per unit volume also correlates well with P-wave velocity (Figure 8D). The axial spatial attenuation for the andesites ranges from 8.39 to $28.74 \mathrm{~dB} / \mathrm{cm}$ (Figure 9). Figure 9 shows that there is no clear trend between spatial attenuation and P-wave velocity. Dynamic Poisson's ratio and dynamic Young's modulus were in the range of 0.13 to 0.23 and 24.6 to $45.9 \mathrm{GPa}$, respectively (Table 3 ). 

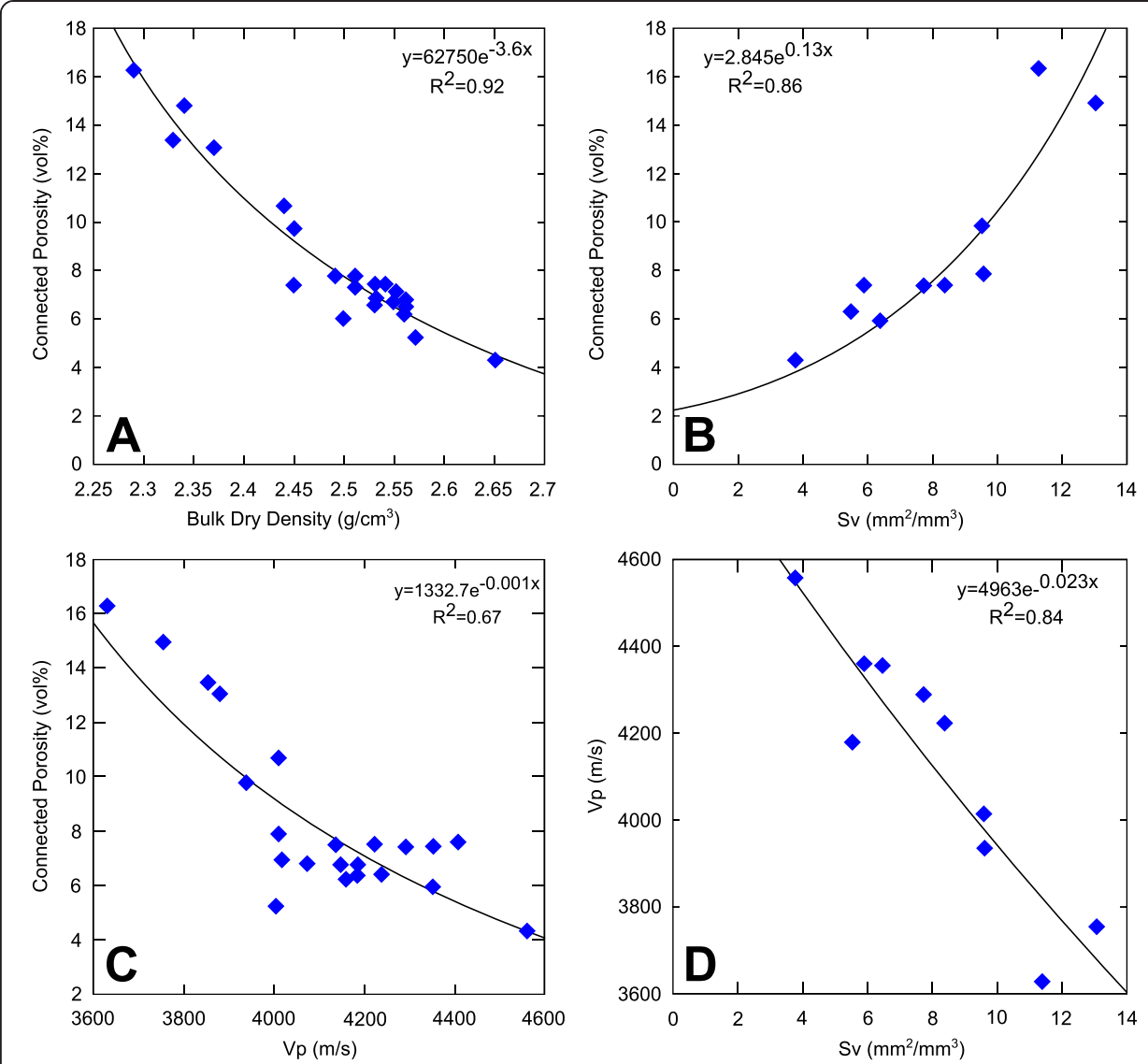

Figure 8 Relationships of porosity, density, crack area, and compressional wave velocity for Rotokawa Andesite. (A) Connected porosity versus dry bulk density for Rotokawa Andesite calculated using the dual weight method of (Ulusay and Hudson 2007). (B) Crack area per unit volume (Sv) plotted versus connected porosity for samples representing the range of values measured within the measured dataset. (C) Connected porosity (vol\%) using the dual weight method versus axial compressional wave velocity $(V p)$ as measured under a stress of $10 \mathrm{MPa}$ which was determined to be below the crack closure stress (see text for further detail). (D) Crack area per unit volume (Sv) versus compressional wave velocity $(\mathrm{VP})$.

\section{Uniaxial compressive strength and static elastic moduli}

In order to characterize the mechanical behavior of the Rotokawa Andesite, the 22 samples of Table 3 were loaded in compression to failure. The dataset shows a large range of UCS (as observed for the other physical properties), from 60 to $211 \mathrm{MPa}$. The stress-strain behavior of the andesites is very similar across the range of strengths, as shown in Figure 10, which reports curves that best represent the dataset and behavior of the Rotokawa Andesite under uniaxial compression. All specimens in the dataset show brittle behavior as evidenced by the stress-strain relationships and bolstered by analysis of the $\mathrm{AE}$ activity. An increase of $\mathrm{AE}$ between dilatancy $\left(\sigma_{\mathrm{cd}}\right)$ and failure is a benchmark of brittle failure (e.g., Brace and Bombolakis 1963; Rutter 1986; Ashby and Sammis 1990; Heap and Faulkner 2008), as seen in Figure 10. Weaker specimens showed lower overall AE energy output than higher strength specimens. Static Young's moduli range between 19.9 and $43.7 \mathrm{GPa}$ and static Poisson's ratio between 0.09 and 0.34. Our data shows that as porosity and crack surface area increases, the UCS of the 
Table 3 Physical property measurements of 22 samples used in destructive testing of Rotokawa Andesite

\begin{tabular}{|c|c|c|c|c|c|c|c|c|c|c|}
\hline $\begin{array}{l}\text { Sample source_well } \\
\text { sample name }\end{array}$ & $\begin{array}{l}\text { Bulk dry } \\
\text { density }\left(\mathrm{g} / \mathrm{cm}^{3}\right)\end{array}$ & $\begin{array}{l}\text { Connected } \\
\text { porosity (vol\%) }\end{array}$ & $V p(m / s)$ & Vs $(\mathrm{m} / \mathrm{s})$ & $\begin{array}{l}\text { Spatial } \\
\text { attenuation }(\mathrm{dB} / \mathrm{cm})\end{array}$ & $\begin{array}{l}\text { UCS } \\
\text { (MPa) }\end{array}$ & $\begin{array}{l}\text { Static Young's } \\
\text { modulus (GPa) }\end{array}$ & $\begin{array}{l}\text { Dynamic Young's } \\
\text { modulus (GPa) }\end{array}$ & $\begin{array}{l}\text { Static } \\
\text { Poisson's ratio }\end{array}$ & $\begin{array}{l}\text { Dynamic } \\
\text { Poisson's ratio }\end{array}$ \\
\hline RK_27_L2_21.5B & 2.44 & 10.72 & 4,005 & 2,443 & 14.63 & 85.99 & 19.9 & 35.1 & 0.24 & 0.2 \\
\hline RK_27_L2_21.8A & 2.33 & 13.49 & 3,850 & 2,363 & 16.47 & 79.91 & 25.2 & 31.2 & 0.26 & 0.2 \\
\hline RK_27_L2_23.2A & 2.56 & 6.61 & 4,182 & 2,490 & 22.48 & 105.26 & 31.2 & 38.9 & 0.19 & 0.23 \\
\hline RK_27_L2_20.4B & 2.65 & 4.37 & 4,556 & 2,752 & 22.53 & 211.05 & 37.7 & 45.9 & 0.25 & 0.21 \\
\hline RK_27_L2_21.1C & 2.37 & 13.1 & 3,877 & 2,405 & 23.6 & 69.53 & 21.5 & 32.5 & 0.18 & 0.19 \\
\hline RK_27_L2_3.3B & 2.45 & 9.81 & 3,937 & 2,331 & 23.51 & 95.78 & 32.4 & 29.9 & 0.13 & 0.18 \\
\hline RK_27_L2_21.0B & 2.34 & 14.91 & 3,752 & 2,337 & 8.4 & 60.13 & 28.1 & 30.6 & 0.12 & 0.17 \\
\hline RK_27_L2_21.3A & 2.29 & 16.3 & 3,627 & 2,160 & 15.13 & 70.57 & 30.4 & 24.6 & 0.16 & 0.17 \\
\hline RK_28_10.6C & 2.5 & 5.97 & 4,350 & 2,652 & 18.27 & 146.2 & 43.7 & 42.4 & 0.27 & 0.2 \\
\hline RK_28_10.8C & 2.53 & 6.72 & 4,147 & 2,537 & 11.67 & 109.91 & 27.2 & 39.1 & 0.34 & 0.2 \\
\hline RK_28_10.9B & 2.51 & 7.42 & 4,285 & 2,615 & 14.67 & 137.31 & 32.4 & 41.5 & 0.2 & 0.2 \\
\hline RK_28_13.2A & 2.55 & 6.97 & 4,013 & 2,531 & 18.53 & 146.21 & 38.3 & 37.2 & 0.24 & 0.19 \\
\hline RK_28_10.5A & 2.45 & 7.47 & 4,220 & 2,578 & 14.83 & 130.71 & 27.4 & 38.8 & 0.25 & 0.21 \\
\hline RK_28_11.5A & 2.51 & 7.62 & 4,403 & 2,555 & 10.06 & 152.76 & 35.6 & 37.4 & 0.27 & 0.13 \\
\hline RK_28_12.1 & 2.49 & 7.89 & 4,010 & 2,460 & 12.23 & 115.01 & 29.3 & 36.2 & 0.22 & 0.14 \\
\hline RK_30_20.4A & 2.57 & 5.3 & 4,002 & 2,495 & 10.39 & 140.97 & 33.6 & 36.9 & 0.09 & 0.15 \\
\hline RK_30_21.0A & 2.55 & 6.84 & 4,070 & 2,508 & 11.17 & 126.53 & 26.4 & 39.8 & 0.14 & 0.15 \\
\hline RK_30_21.1B & 2.54 & 7.47 & 4,352 & 2,659 & 28.75 & 157.93 & 25.8 & 43.2 & 0.17 & 0.2 \\
\hline RK_30_21.7B & 2.56 & 6.28 & 4,154 & 2,588 & 19.91 & 162.71 & 28.3 & 41.1 & 0.22 & 0.18 \\
\hline RK_30_22.3B & 2.53 & 7.51 & 4,133 & 2,550 & 21.72 & 137.97 & 31.5 & 39.2 & 0.23 & 0.19 \\
\hline RK_30_22.4A & 2.56 & 6.49 & 4,181 & 2,582 & 20.27 & 148.44 & 34.4 & 40.7 & 0.18 & 0.19 \\
\hline RK_30_22.5B & 2.56 & 6.41 & 4,236 & 2,628 & 23.43 & 150.71 & 33.6 & 42.1 & 0.09 & 0.16 \\
\hline Mean & 2.49 & 8.44 & 4,106 & 2,510 & 17.39 & 124.62 & 30.6 & 37.5 & 0.2 & 0.18 \\
\hline Standard deviation & 0.09 & 3.23 & 221 & 133 & 5.512 & 37.01 & 5.5 & 5.1 & 0.06 & 0.03 \\
\hline
\end{tabular}




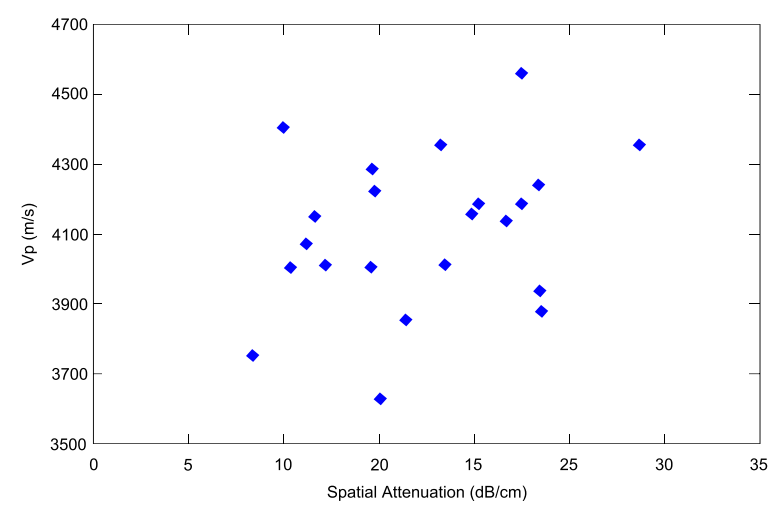

Figure 9 Spatial attenuation $\left(\mathrm{a}_{\mathrm{s}}\right)$ of axial compressional P-wave velocity of Rotokawa Andesite.

Attenuation was calculated by the method suggested by Martínez-Martínez et al. (2011) utilizing transmission of the ultrasonic wave and maximum attenuation of the waveform plotted versus axial compressional wave velocity (Vp) obtained under an axial stress of $10 \mathrm{MPa}$.

rock decreases (Figure 11A,B). Further, the UCS increases as axial P-wave velocity increases (Figure 11C).

\section{Permeability}

Our argon permeability measurements show that for the tested samples, permeability ranges from $9.82 \times 10^{-18} \mathrm{~m}^{2}$ to $1.66 \times 10^{-16} \mathrm{~m}^{2}$ (Table 4). The results show a trend of increasing permeability with increasing porosity (Figure 11E). We observe that three of the samples contain macrofractures (black stars on Figure 11E,F) and have higher permeabilities that slightly deviate from the trend of the dataset. We also note that as permeability increases, the axial compressional wave velocity decreases (Figure 11F); further, those samples with distinct macrofractures show lower compressional velocities and higher permeabilities when compared with samples of similar porosity.

\section{Discussion}

\section{Micromechanical interpretation}

We have shown that the Rotokawa Andesite contains a pervasive network of isotropic microcracks. Due to their isotropic distribution, the majority of these microcracks are consistent with the results of thermal stressing (Fredrich and Wong 1986; Reuschlé et al. 2006; Wang et al. 1989; David et al. 1999; Heap et al. 2014). Indeed, the Rotokawa Andesite has experienced several cycles of heating and cooling: the initial eruption of the andesite, burial in a faulted graben, hydrothermal alteration, and the eventual exhumation during core recovery (Rae 2007; Lim et al. 2012). Our microstructural analysis has highlighted that the pervasive microcracking appears independent of lithology, original mineralogy, and secondary (hydrothermal alteration) mineralogy.

The intense microcracking in our samples has shown to be a significant factor in all of the measured physical properties. First, microcracking has greatly reduced the propagation velocity of elastic waves through the andesite. We see a clear correlation of crack area per unit volume (Sv) to the observed compressional wave velocities (Figure 8D) and interpret this to be attenuation of the compressional wave through the cracked intracrystalline and intercrystalline boundaries that are abundant in the andesite (e.g., Figures 3 and 4). Many authors (e.g., Vinciguerra et al. 2005; Keshavarz et al. 2010; Blake et al. 2012; 

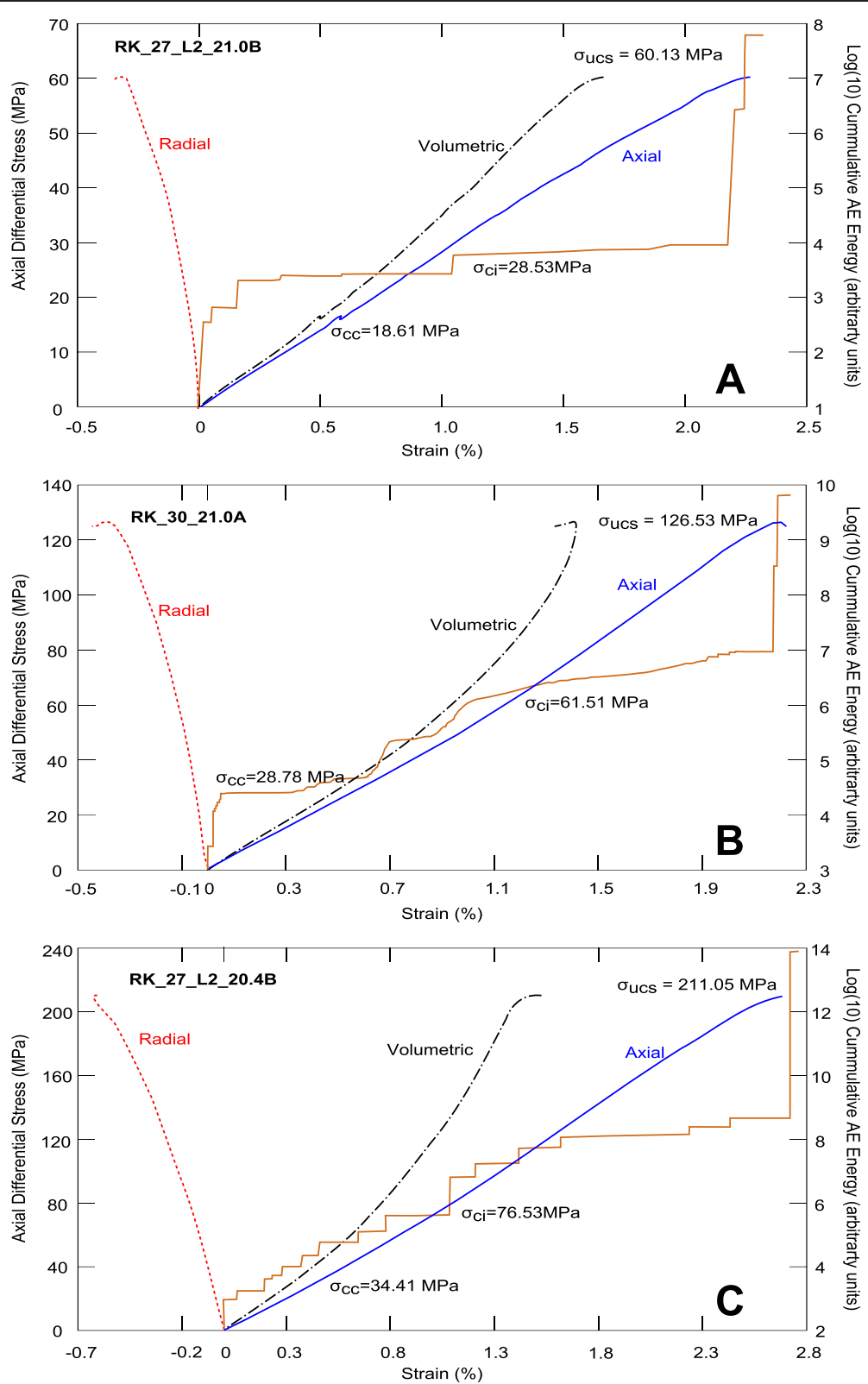

Figure 10 Stress-strain behavior of the Rotokawa Andesite. Samples were subject to constant strain rate loading $\left(1 \times 10^{-5} / \mathrm{s}\right)$ and monitored for associated arbitrary acoustic emission energy output. All samples in this study display brittle failure. (A) Samples with low UCS generally develop a single fracture plane. (B) Samples near mean UCS develop several fracture planes. (C) Samples with very high UCS showed explosive, catastrophic failure into several large and small pieces with no distinct failure plane.

Heap et al. 2014) have also shown that the elastic wave velocities can be highly attenuated by the presence of microcracks.

Second, the crack surface area and UCS have yielded an excellent correlation (Figure 11B). As noted by Walsh (1965a, b), David et al. (1999), and Chaki et al. (2008), the density of the cracks within a specimen is critical in dictating its strength. The development of microcracks during uniaxial compression, and the coalescence of these cracks (newly formed and pre-existing), leads to the failure of the sample (Brace et al. 1966; Bieniawski 1967). In samples that already show relatively high crack densities, less 

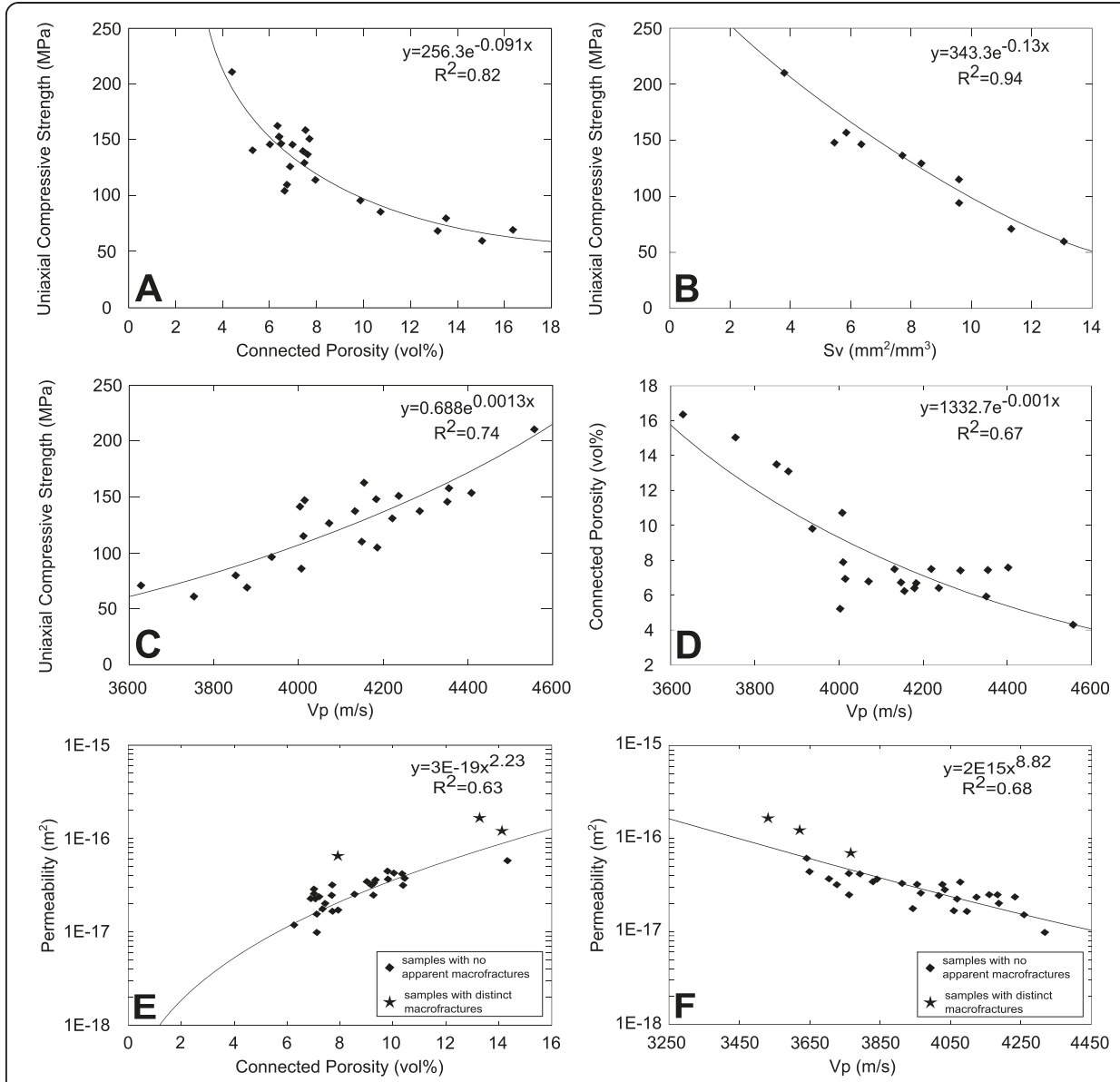

Figure 11 Key empirical relationships of the Rotokawa Andesite. (A) Connected porosity (vol\%) plotted versus uniaxial compressive strength (MPa) for Rotokawa Andesite at ambient pressures and temperatures. (B) Crack area per unit volume (Sv) as measured from reflected light thin sections (method recommended by Underwood 1970) plotted versus uniaxial compressive strength (UCS) for the Rotokawa Andesite. (C) Axial P-wave velocity (Vp) as measured at ambient temperatures under an axial load of $10 \mathrm{MPa}$ versus uniaxial compressive strength values for the Rotokawa Andesite at ambient temperature. (D) Axial compressional wave velocity (Vp) plotted versus connected porosity (vol\%) as measured by the dual weight method (Ulusay and Hudson 2007). (E) Semi-log plot of connected porosity measured by the tripleweight method (Ulusay and Hudson 2007) versus argon gas permeability with effective pressure of $0.5 \mathrm{MPa}$. (F) Semi-log plot of axial compressional wave velocity (Vp) plotted versus argon gas permeability.

energy is required to coalesce existing cracks and thus they are inherently weaker (David et al. 1999; Ferrero and Marini 2001; Keshavarz et al. 2010). By utilizing AE monitoring during our UCS testing, we observe that fewer events occur during uniaxial compression in weaker samples than those with higher strength (Figure 10), indicating that there are far more pre-existing cracks in the weaker samples (Hardy 1981; Eberhardt et al. 1998; Nicksiar and Martin 2012). Thus, the presence of pre-existing microcracks in the Rotokawa Andesite is shown to exert a strong control on their uniaxial compressive strength.

Permeability is one of the most important properties of a geothermal system. In this study, we have seen that porosity (and bulk sample density) and strength are related to the extent of the microcracking in the andesite. We did not measure the crack surface area in the samples used for our permeability measurements (the samples will be used for future studies; calculating crack surface area required destructive thin section 
Table 4 Results of density, porosity, argon permeability, and acoustic velocity measurements for Rotokawa Andesite

\begin{tabular}{|c|c|c|c|c|}
\hline $\begin{array}{l}\text { Sample source: well } \\
\text { number, depth, name }\end{array}$ & $\begin{array}{l}\text { Bulk dry } \\
\text { density }(\mathrm{g} / \mathrm{cm} 3)\end{array}$ & $\begin{array}{l}\text { Connected } \\
\text { porosity (vol\%) }\end{array}$ & $\begin{array}{l}\text { Argon } \\
\text { permeability }\left(\mathrm{m}^{2}\right)\end{array}$ & $\begin{array}{l}\text { Axial P-wave } \\
\text { velocity }(\mathrm{m} / \mathrm{s})\end{array}$ \\
\hline RK_27_L2_2120.4A_1 & 2.55 & 7.24 & $1.78 \mathrm{E}-17$ & 3,943 \\
\hline RK_27_L2_2120.4A_2 & 2.55 & 7.06 & $9.82 \mathrm{E}-18$ & 4,318 \\
\hline RK_27_L2_2121.1A & 2.34 & 13.97 & $1.25 \mathrm{E}-16$ & 3,621 \\
\hline RK_27_L2_2123.3A_1 & 2.48 & 9.22 & $3.32 \mathrm{E}-17$ & 3,911 \\
\hline RK_27_L2_2123.3A_2 & 2.46 & 10.25 & 4.13E-17 & 3,793 \\
\hline RK_27_L2_2123.7A_1 & 2.52 & 9.73 & $3.69 \mathrm{E}-17$ & 3,840 \\
\hline RK_27_L2_2123.7A_2 & 2.50 & 10.35 & $3.72 \mathrm{E}-17$ & 3,704 \\
\hline RK_27_L2_2124.1B_1 & 2.54 & 7.63 & $3.24 \mathrm{E}-17$ & 3,954 \\
\hline RK_27_L2_2124.1B_2 & 2.56 & 6.93 & $2.81 \mathrm{E}-17$ & 4,032 \\
\hline RK_27_L2_2121.0A_1 & 2.42 & 13.14 & $1.66 \mathrm{E}-16$ & 3,532 \\
\hline RK_27_L2_2121.0A_2 & 2.33 & 14.23 & $6.09 \mathrm{E}-17$ & 3,642 \\
\hline RK_28_2310.3A_1 & 2.46 & 9.94 & $4.26 \mathrm{E}-17$ & 3,760 \\
\hline RK_28_2310.3A_2 & 2.48 & 9.70 & 4.44E-17 & 3,650 \\
\hline RK_28_2310.8A_1 & 2.50 & 8.95 & $3.45 \mathrm{E}-17$ & 3,830 \\
\hline RK_28_2310.8A_2 & 2.50 & 9.22 & $3.43 \mathrm{E}-17$ & 4,076 \\
\hline RK_28_2310.9C_1 & 2.46 & 10.30 & $3.21 \mathrm{E}-17$ & 3,725 \\
\hline RK_28_2310.9C_2 & 2.53 & 7.64 & $1.65 \mathrm{E}-17$ & 4,096 \\
\hline RK_28_2311.1B_1 & 2.55 & 7.04 & $1.53 \mathrm{E}-17$ & 4,259 \\
\hline RK_28_2311.1B_2 & 2.56 & 7.35 & $2.05 \mathrm{E}-17$ & 4,190 \\
\hline RK_28_2311.3B_1 & 2.50 & 9.10 & $3.21 \mathrm{E}-17$ & 4,026 \\
\hline RK_28_2311.3B_2 & 2.49 & 9.17 & $2.50 \mathrm{E}-17$ & 4,183 \\
\hline RK_30_2320.6A_1 & 2.53 & 7.90 & 7.10E-17 & 3,765 \\
\hline RK_30_2320.6A_2 & 2.56 & 7.79 & $1.70 \mathrm{E}-17$ & 4,061 \\
\hline RK_30_2321.0B_1 & 2.50 & 8.24 & $2.50 \mathrm{E}-17$ & 3,762 \\
\hline RK_30_2321.0B_2 & 2.54 & 8.47 & $2.50 \mathrm{E}-17$ & 4,164 \\
\hline RK_30_2321.2B_1 & 2.58 & 7.11 & $2.38 \mathrm{E}-17$ & 4,235 \\
\hline RK_30_2321.2B_2 & 2.55 & 6.98 & 2.37E-17 & 4,122 \\
\hline RK_30_2321.5A & 2.57 & 6.92 & $2.60 \mathrm{E}-17$ & 3,965 \\
\hline RK_30_2322.3A_1 & 2.54 & 7.61 & $2.44 \mathrm{E}-17$ & 4,016 \\
\hline RK_30_2322.3A_2 & 2.57 & 6.83 & $2.27 \mathrm{E}-17$ & 4,069 \\
\hline
\end{tabular}

preparation). However, we can, by proxy, assume a correlation between permeability and the extent of the microfracture network. We show that there is a clear inverse relationship between the sample's permeability and P-wave velocity such that as permeability increases, compressional wave velocity decreases (Figure 11F). These results are consistent with the many investigations have shown a clear link between reduced elastic wave velocities and increased permeability (David et al. 1999; Vinciguerra et al. 2005; Chaki et al. 2008; Nara et al. 2011; Faoro et al. 2013; Heap et al. 2014). While we have not measured the relationship of crack density to permeability directly in our dataset, we show that $\mathrm{Sv}$ and $\mathrm{Vp}$ are inversely related (Figure 8D), and a similar relationship exists between $\mathrm{Vp}$ and permeability. Therefore, we can infer that those samples with higher crack surface areas will be inherently more permeable. 


\section{Key empirical relationships}

In this section, we present relationships of singular variables that could be readily and easily measured either using photomicrography or geophysical logging tools and their correlation to more complicated and pertinent physical properties. All of these parameters are singularly measurable variables that do not rely on complex formulae for their derivation (such as dynamic Young's Modulus or Poisson's ratio) and so have been selected to be the key relationships that we present with relevance to the Rotokawa Andesite.

\section{Porosity and UCS}

An exponential correlation between sample porosity and UCS exists (Figure 11A). Such correlations have been utilized by several authors (e.g., Vernik et al. 1993; Li and Aubertin 2003; Palchik and Hatzor 2002; Kahraman et al. 2005; Chang et al. 2006; Palchik 2013; Pola et al. 2014) for a variety of clastic and volcanic rocks and concrete materials. These authors present empirical fits for the correlation of physical properties versus UCS and show a wide range of correlation within their respective datasets with $R^{2}$ values from near 0.6 to as high as 0.95 . We propose that our empirical fit between porosity and UCS (an exponential fit with a correlation factor of 0.82, Figure 11A) can provide useful estimations of the strength of the reservoir rocks within the Rotokawa Andesite reservoir. By utilizing estimations of UCS derived from the correlation of porosity, the minimum strength of the rocks can be applied to important engineering issues such as wellbore stability (Chang et al. 2006; Schöpfer et al. 2009).

\section{Vp and UCS}

There is an exponential correlation between strength and $\mathrm{Vp}$ with an $R^{2}$ value of 0.74 (Figure 11C). As noted by Kahraman (2001), the relationship between Vp and UCS is generally nonlinear and the higher the strength of the material, the more scattered the data points. Heap et al. (2014) came to similar conclusions following measurements on andesitic rocks from Volcán de Colima (Mexico). In our study, there is an increasing trend of strength with increasing Vp but, as shown in Figure 9, there is a high degree of spatial anisotropy with respect to $\mathrm{Vp}$ such that a robust correlation of strength to elastic wave velocity is difficult to obtain. However, $\mathrm{Vp}$ is a widely utilized logging tool in borehole geophysics (Chang et al. 2006), and using the correlation that we have obtained, a minimum strength criteria could be established from the response of the logging tool. This is an important correlation as geophysical logging is much easier, faster, and more efficient than cutting spot cores (as the core for this study was obtained), and so the development of empirical correlations to constrain strength such as that seen in Figure 11B can help mitigate risk and reduce the cost associated with geothermal drilling programs.

\section{Vp and porosity}

Correlations between $\mathrm{Vp}$ and porosity show an increasing trend of porosity with decreasing Vp (Figure 11D, also observed by Al-Harthi et al. 1999; Rajabzadeh et al. 2011; Tugrul and Gurpinar 1997; Heap et al. 2014). This can be attributed to both the pore structure distribution and the degree of microcracking within the andesites. It is clear from microstructural analysis (using both optical and scanning electron microscope 
analyses) that a large proportion of the porosity in the Rotokawa Andesite is likely to be composed of (macro- and mesoscale) fractures and microcracks (e.g., Figures 6 and 7).

An explanation for the variation and wide distribution of the elastic wave velocity data for samples with similar porosities (specifically with regard to those data that range from 4,000 to $4,400 \mathrm{~m} / \mathrm{s}$ ) is that there must be a variable pore (vug/vesicle) content or hydrothermal alteration between the samples. The presence of pores will greatly augment the porosity (due to their aspect ratio) but will have comparatively little influence, compared to the microcracks, on the P-wave velocity. The application of our exponential relationship (Figure 11D) can give a rough approximation for seismic velocities derived from connected porosity, or vice versa. This may be useful during the drilling of additional wells at Rotokawa where porosity can be measured at the wellsite and yield a rough approximation for P-wave velocities and, as such, tie back to our empirical correlations of strength (Figure 11C).

\section{Permeability and porosity}

Our permeability and porosity data show that there is a clear trend of increasing porosity with increased permeability for the Rotokawa Andesite (Figure 11E), a common observation in multiple lithologies (e.g., Heard and Page 1982; Géraud 1994; Stimac et al. 2004; Chaki et al. 2008; Watanabe et al. 2008; Heap et al. 2014). We observe that our relationship between porosity and permeability can be described by a power law correlation and is consistent with the Kozeny-Carman relation (Guéguen and Palciauskas 1994, see the 'Application of micromechanical and geometrical permeability models' section). The dependence of permeability on porosity is generally explained by the assumption that a more connected pore space (cracks and pores) provides more efficient pathways for fluid migration (e.g., Costa 2006; Chaki et al. 2008). We do however need to consider those data points that have a very similar value of permeability (approximately $3.2 \times 10^{-17} \mathrm{~m}^{2}$, Table 4), with a porosity range of 7.6 to $10.3 \mathrm{vol} \%$ that indicate that there is variability of the samples with respect to permeability that may be reflected in the tortuosity of the porous network. This is consistent with the findings of Bernard et al. (2007) and Heap et al. (2014) such that the permeability in volcanic rocks is highly dependent upon connectivity of the microstructure.

With respect to microstructure, we have shown that the porosity is very closely linked to crack surface area (Figure 8D) and, thus, that increasing crack density corresponds to a sample with a higher permeability. The three samples that lie slightly outside the trend of the dataset display distinct mesofractures (black stars in Figure 11E,F) and that these mesofractures greatly enhance the permeability of the samples without significantly increasing their porosity. These specimens show higher than average permeability for their porosity, which supports the conclusions of Stimac et al. (2008) that meso- and macrofractures are critical in controlling the permeability of geothermal reservoir systems. On the large scale, macrofractures are necessary for fluid production from geothermal reservoirs, but the microstructural characteristics of the host rocks cannot be neglected when considering fluid flow, storage capacity, and total permeability of the reservoir (Jafari and Babadagli 2011).

The robust relationship between porosity and permeability has wider-scale reservoir applications where the need to understand reservoir rock permeability (the mass itself, not those portions with highly macroscopic fractures e.g., Massiot et al. 2012) is important 
for reservoir forecasting and modeling. Measurements of porosity can then yield a good approximation of the permeability of the intact reservoir rock at Rotokawa through our power law correlation (Figure 11E). However, we urge caution if the porosity falls outside our measured range. As porosity is a readily measureable property by geophysical logging tools (Ellis and Singer 2008), the response from such a tool, together with our empirical fit, can give engineers and geoscientists an approximation of the matrix permeabilities in the Rotokawa Andesite.

\section{Permeability and acoustic velocities}

There is a clear inverse relationship between our measurements of permeability and P-wave velocity (Figure 11F) such that the more permeable the sample, the slower the compressional wave velocity. These findings are consistent with the findings of many other authors (e.g., Vinciguerra et al. 2005; Chaki et al. 2008; Nara et al. 2011; Heap et al. 2014). The correlation of such properties is an excellent tool for understanding the micro- and mesoscopic fracture networks and their relation to permeability in the Rotokawa Andesite as follows: (1) we have shown that the porosity and crack density are closely linked (Figure 8A), (2) acoustic velocity and crack density are closely linked (Figure $8 \mathrm{D}$ ), and (3) there is a power law correlation of $\mathrm{Vp}$ and permeability (Figure 11F). Thus, there is a direct link of P-wave velocity to permeability that is reliant on the crack densities of the samples. The relationship we present in Figure 11F shows a power-law fit which would indicate that the hydraulic radii of the pore space (pore and cracks) are similar in size but that the higher the concentration of cracks, the higher the permeability we observe (Bourbie and Zinszner 1985).

Similarly, there are occasional mesofractures (with apertures less than 1-mm width; we note that these fractures are much smaller than those described in Massiot et al. 2012) in the samples that deviate from the rest of the dataset (black stars, Figure 11F). The presence of these macrofractures increases permeability (by a factor of 2) and also appears deleterious to elastic wave propagation (all the three samples containing mesofractures have low elastic wave velocities, although we cannot separate the influence of meso- and microcracks on the velocities of these samples). Further, elastic waves are useful for the detection of cracks in rock and concrete (Chaki et al. 2008; Heap et al. 2013), and a decreased elastic wave velocity correlates well to more permeable media which is observed by the three outlying, higher permeability, lower elastic wave velocity samples.

The correlation between elastic wave velocity and permeability outside the laboratory has potentially far-reaching value for the prediction of reservoir permeability interactions from wireline logging and larger-scale seismic and microseismic surveys. There is a complex microseismic network installed at Rotokawa, and the location of earthquake activity has been closely linked to macroscopic permeability within the reservoir (Sewell et al. 2013; Sherburn et al. 2013). The existing model of the velocity structure at depth could then be further refined using our acoustic velocity and permeability data for reservoir rock matrix. This may allow a deeper and more accurate understanding of the distribution of permeability at depth.

Additionally, the data we have presented can also be used to infer values of matrix permeability from acoustic wireline logs (dipole sonic) used during exploration at nearby Ngatamariki Geothermal Field (Wallis et al. 2009). Should similar geophysical logging be 
used in future wells drilled at Rotokawa, the matrix permeability may be estimated using the relationship we present here. In addition, the coupling of these data with microseismic data could allow a significant increase in understanding the complexity of the Rotokawa Andesite reservoir. While we are aware that macrofractures augment the elastic wave velocity during routine acoustic profiling (e.g., Barton and Zoback 1992), our laboratory data show that although samples containing mesofractures (i.e., on the sample scale) are shifted to higher permeabilities and elastic wave velocities, they do not stray too far away from the trend extrapolated from our power-law relationship. Despite this, we urge a certain degree of caution, based on the potential presence of large-scale fractures, when estimating permeability using our derived permeability-elastic wave velocity relationship.

\section{Application of micromechanical and geometrical permeability models}

Extracting empirical relationships between laboratory-derived rock properties is useful; however, the parameters are not easily related to independently measurable quantities (i.e., they lack a physical basis). Micromechanical (e.g., the wing-crack model of Ashby and Sammis 1990) and geometrical permeability models (e.g., the Kozeny-Carman relation, Guéguen and Palciauskas 1994) can be better constrained as the parameters used in such models have a clear physical meaning. In this section, we attempt both sliding wing-crack modeling and Kozeny-Carman permeability modeling to investigate the microstructural controls on deformation and fluid flow, respectively.

\section{Micromechanical modeling}

Micromechanical modeling can provide useful insights in the mechanics of compressive failure in brittle rock (Wong and Baud 2012). Since the rocks of this study contain high microcrack densities, we will use the sliding wing-crack model of Ashby and Sammis (1990). This model idealizes the rock microstructure as an elastic continuum embedded with inclined $\left(45^{\circ}\right)$ microcracks (of length 2c). These microcracks act as stress concentrators for the initiation of 'wing' cracks when the frictional resistance of the closed crack is overcome and the stress at the tip of the crack exceeds the critical stress intensity factor $\left(K_{\mathrm{IC}}\right)$. The cracks can then propagate in the direction of the maximum principal stress. Eventually, the cracks coalesce, resulting in the failure of the elastic medium. In the case of uniaxial compression, Baud et al. (2014) derived an analytical approximation to estimate UCS:

$$
\mathrm{UCS}=\frac{1.346}{\sqrt{1+\mu^{2}-\mu}} \frac{K_{\mathrm{Ic}}}{\sqrt{\pi c}} D_{0}^{-0.256}
$$

where $\mu$ is the friction coefficient of the sliding crack and $D_{0}$ is an initial damage parameter that is a function of the angle of the initial microcrack with respect to the maximum principal stress and the initial number of sliding cracks per unit area (Ashby and Sammis 1990).

The analytical solution (that assumes an initial crack angle of $45^{\circ}$ ) presented above contains five parameters. We have, through experimental data and observations, a good handle on three of the parameters: (1) we have measured the UCS of 22 samples (Table 3), (2) $\mu$ rarely deviates from 0.6 to 0.7 (Byerlee 1978), and (3) $c$ can be determined from optical microscopy (we determined $c$ by measuring the approximate average length of the microcracks under the microscope). We do not have a laboratory-determined value 
for $K_{\mathrm{IC}}$. While the $K_{\mathrm{IC}}$ of andesite has been previously measured to be about $1.5 \mathrm{MPam}^{0.5}$ (Ouchterlony 1990; Obara et al. 1992; Tutluoglu and Keles 2011; Nara et al. 2012), there is no guarantee that this value is representative of the Rotokawa Andesite, which is likely to be lower than these values due to hydrothermal alteration. We therefore have chosen a slightly lower $K_{\mathrm{IC}}$ of $1.0 \mathrm{MPam}^{0.5}$ for our analysis. Using our UCS data, we can solve Equation 10 to assign a value of $D_{0}$ to each experiment (using $\mu=0.6 ; K_{\mathrm{IC}}=1.0 ; c=$ $0.001 \mathrm{~m}$ ). The goal of such analysis, assuming that the other parameters remain roughly constant between different samples/cores, is to estimate $D_{0}$ using an easily measured physical property, such as $\mathrm{Vp}$ (therefore allowing us to predict rock strength, using the micromechanical model, from $\mathrm{Vp}$ measurements alone). Our analysis shows that $D_{0}$ ranges from 0.0019 to 0.26 for the 22 measured samples (with average of 0.039 ). $D_{0}$ is plotted against the crack area per unit volume (Sv) and Vp in Figure 12 and indicates that $D_{0}$ increases as $\mathrm{Sv}$ increases (Figure 12A). While this may appear logical $\left(D_{0}\right.$ is a function of the initial crack density), it serves as an encouraging proof of the concept. The increase in $D_{0}$ with crack density is not linear; $D_{0}$ increases more rapidly beyond $10 \mathrm{~mm}^{-1}$ (Figure 12A). We also see that $\mathrm{Vp}$ decreases with increasing $D_{0}$; in detail, $\mathrm{Vp}$ decreases rapidly as $D_{0}$ increases from 0 to 0.05 and then decreases more gradually above 0.05 . Unfortunately, the relationship between $D_{0}$ and $\mathrm{Vp}$ is a little more clouded (the data are more scattered, Figure 12B) and probably represents variable vesicle density (the model assumes that vesicles do not play a role in failure in compression) and hydrothermal alteration (we assume that $K_{\mathrm{IC}}$ and the average crack lengths are constant). The conclusion of this pilot analysis is that the variability within the Rotokawa Andesite is potentially too large to permit meaningful microstructural wing-crack modeling, but greater success could be achieved with laboratory-determined values for $K_{\mathrm{IC}}$. Therefore, if micromechanical modeling is to be deployed as a feasible method to predict the strength of Rotokawa Andesite reservoir rocks, the samples/cores should be grouped by their alteration, and $K_{\mathrm{IC}}$ measured for each alteration group.

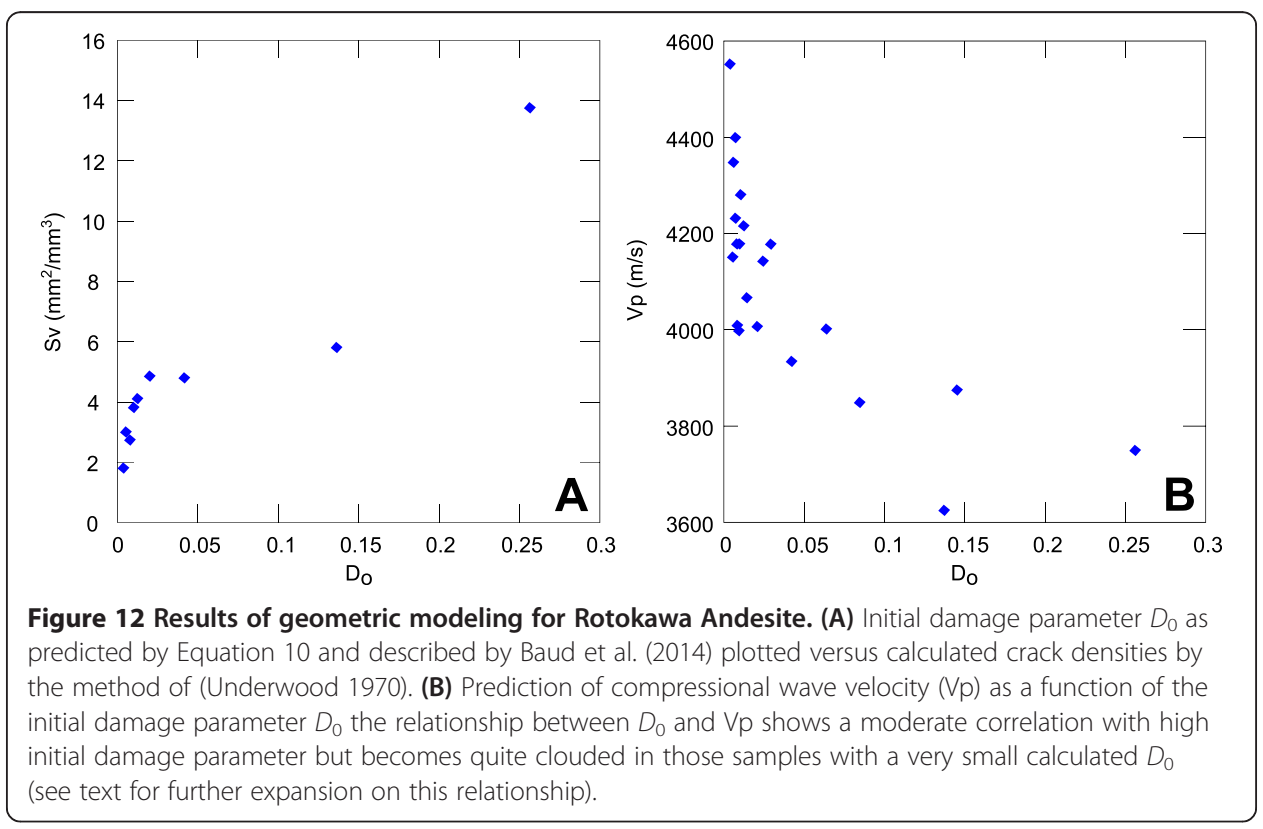




\section{Permeability modeling}

Kozeny-Carman models are those that use the notion of a hydraulic radius (see Guéguen and Palciauskas 1994) to correlate porosity and permeability. Forms of the KozenyCarman relation have previously been used in the study of volcanic rocks (e.g., Saar and Manga 1999; Costa 2006; Bernard et al. 2007; Heap et al. 2014), while others have used a heavily simplified version (e.g., Rust et al. 2003; Mueller et al. 2005; Lavallée et al. 2013). The Kozeny-Carman relation is of the form:

$$
k_{\mathrm{KC}}=\frac{\varphi\left(r_{\mathrm{H}}\right)^{2}}{b \tau^{2}}
$$

where $k_{\mathrm{KC}}$ is the permeability, $\varphi$ is the connected porosity, $b$ is a geometrical factor, $\tau$ is the tortuosity of the equivalent channel (i.e., the ratio of its actual to nominal length), and $r_{\mathrm{H}}$ is the hydraulic radius (i.e., the volume of pores divided by the surface of the pores). The power law exponent for our data (excluding those samples with macrofractures) is about 2.2 (Figure 11E) and is therefore consistent with the Kozeny-Carman model (Bourbie and Zinszner 1985; Doyen 1988). In detail, one would expect a power law exponent of 2 or 3 if the elements controlling the permeability are tubes or cracks, respectively (Guéguen and Palciauskas 1994). Our power law exponent is between these two values. This is somewhat surprising, considering the pervasive fracture network in these materials, but could reflect flow through a combination of cracks and tubes or our limited porosity range. Since the entire dataset can be described by a single power law exponent, we conclude that within our limited range of connected porosities, there is no dramatic shift in pore space connectivity or tortuosity, as was the case for Fontainebleau sandstone at a porosity of 9 vol\% (Bourbie and Zinszner 1985) and andesite samples from Volcán de Colima (Mexico) at a porosity of about 11 vol\% (Heap et al. 2014). Extrapolating to porosities outside this range may be treacherous especially to lower porosities where samples may become subject to a higher power law exponent. However, within the dataset, the model predicts an increase in permeability of a factor of 1.5 for an increase in porosity of 1 vol\% (an increase not uncommon for rock following a thermal stressing episode; e.g., Chaki et al. 2008).

\section{Application of results to geothermal exploration and utilization}

The relationships between porosity, acoustic wave velocities, strength, and permeability are valuable for understanding a geothermal reservoir. Our data indicate strong correlations between these parameters, as observed by Stimac et al. (2004, 2008) amongst others. The data we have obtained are from cores sourced from three production wells. Such materials are very expensive to obtain, time consuming, and, if coring did not go as planned, can pose great risk of losing the well (Finger and Blankenship 2010; Hole 2013). The microstructural and empirical correlations presented in this study can be applied to new wells drilled in geothermal environments and can help refine studies on pre-existing wells, if our correlations hold true at the reservoir scale. Some physical parameters, such as porosity and elastic wave velocities, are easily obtainable through the use of down-hole geophysical logging suites. The empirical correlations shown in this study (bolstered by our application of classical models) show that readily measurable physical properties may therefore be used to predict more complex and pertinent properties such as strength and permeability. Such correlations and calibrations are common in 
the hydrocarbon industry especially during exploration drilling (e.g., Vernik et al. 1993 and references therein), and we consider that our dataset can help improve the understanding of the Rotokawa reservoir while minimizing the risk to future drilling operations.

A clear understanding of the factors that control reservoir rock permeability is fundamental for the planning of stimulation and enhancement operations that may be necessary as the Rotokawa field and reservoir dynamics change with continued production. The need to drill additional wells or re-work pre-existing wells may become apparent and the ease at which the reservoir can accept and deliver fluids (i.e., its permeability) will be of utmost importance. The thermal stimulation of injection wells has taken place at Rotokawa for some time by the injection of power-plant condensates and spent brines (Siega et al. 2009), but the technique may play a significant role in enhancing production wells at some future stage.

Therefore, a deeper understanding of how permeability may be increased through stimulation is important. The application of models such as the Kozeny-Carman may provide insight to permeability enhancement. An increase in the porosity of reservoir rock by $1 \mathrm{vol} \%$, according to the geometrical model, should increase the permeability by a factor of 1.5. In the case of an aging field and aging wellbores, such an increase could greatly extend the life of the field. In the interests of keeping geothermal projects commercially economic, the fundamental understanding of the reservoir rock properties become essential to the continued utilization and management of the field.

\section{Conclusions}

Our study provides a comprehensive evaluation of the physical and mechanical properties of the Rotokawa Andesite through a multi-disciplinary approach. We have evaluated the Rotokawa Andesite from the microstructural to macroscopic scale and have presented robust datasets that permit the correlation and comparison of important physical properties to geothermal exploitation. A comprehensive understanding of how the relationships of microstructural texture influence key physical properties such as strength and permeability, essential for the optimal utilization of a geothermal resource have been investigated.

Further, we summarize our conclusions as follows:

1. We have shown that the presence and intensity of microfracturing in the Rotokawa Andesite are the predominant controlling factors on physical and mechanical properties. The behavior of these properties is also shown to be largely independent of the alteration mineralogy as we see similar alteration intensities in the samples we have studied.

2. Guided by a systematic understanding of role of microfractures, we show that empirical correlations of strength and porosity can be developed and applied to field scale engineering problems. We have shown that as the porosity increases, the strength decreases and elastic wave velocities are attenuated. Similarly, we show that permeability increases with increased porosity and reduced acoustic velocity. These findings are applicable if geophysical logging tools be used after the drilling of wells to ascertain properties such as porosity; our dataset provides useful means to address complex reservoir problems. 
3. We further boost our empirical correlations by applying classical physical models based on sound physical theory to predict both UCS and permeability through understanding of the microstructure. We have applied these models with some success, but these models are best-suited for homogeneous, isotropic materials. Further work to constrain these models should include laboratory investigations of fracture toughness $\left(K_{\mathrm{IC}}\right)$ and the factors that influence this variable. However, our fit for the damage criterion $D_{0}$ is acceptable and builds the foundations for future understanding and may permit the construction of similar better constrained models.

4. The study comprises a large dataset with a goal to further push the knowledge that can be sourced from a geothermal environment such as the Rotokawa Andesite. The properties that we have evaluated are very difficult to constrain without direct information from rocks sourced from the reservoir. Geothermal reservoirs are complex, and harsh environments from which the recovery of intact core can present a significant and financially risky challenge. The results that we present here help us to understand this complex reservoir environment by their application to field scale engineering and geological issues.

5. Our analyses have provided quantifiable and measurable physical properties of the Rotokawa Andesite. However, the dataset is not exhaustive. Further studies need to be carried out to replicate near-reservoir conditions in the laboratory and should focus on permeability at the high confining pressures and temperatures found in the reservoir. Additionally, mechanical testing such as triaxial, tensile strength, and fracture toughness experiments should be conducted under high-temperature conditions, potentially in the presence of reservoir-type fluids to aid in predictions of reservoir behavior and geomechanical modeling under conditions as close as possible to those found in the reservoir.

\section{Acknowledgements}

The authors wish to thank Mighty River Power Company Ltd. for a generous grant for PS, which allowed collaboration with MH and TR. We also wish to thank the Rotokawa Joint Venture, a joint venture between the Tauhara North No. 2 Trust and Mighty River Power Company Ltd. for the core material used in this study. The staff of the Department of Geological Sciences at the University of Canterbury were invaluable in assisting in all aspects of this research. The Brian Mason Trust also provided for the transportation and delivery of the core to UC. The authors of this study also acknowledge a Hubert Curien Partnership (PHC) Dumont d'Urville grant (grant number 31950RK) which has assisted the France-New Zealand collaboration for this and future projects. MH was partly funded by the LABEX ANR-11-LABX0050_G-EAU-THERMIE-PROFONDE framework (funding from the state managed by the French National Research Agency as part of the Investments for the Future Program).

\section{Author details}

${ }^{1}$ Department of Geological Sciences, University of Canterbury, Private Bag 4800, Christchurch 8140, New Zealand. ¿Laboratoire de Déformation des Roches, Équipe de Géophysique Expérimentale, Institut de Physique de Globe de Strasbourg (UMR 7516 CNRS, Université de Strasbourg/EOST), 5 rue René Descartes, Strasbourg cedex 67084, France. 


\section{References}

Al-Harthi AA, Al-Amri RM, Shehata WM (1999) The porosity and engineering properties of vesicular basalt in Saudi Arabia. Eng Geol 54:313-320

Ashby MF, Sammis CG (1990) The damage mechanics of brittle solids in compression. Pure Appl Geophys 133:489-521

Barton CA, Zoback MD (1992) Self-similar distribution and properties of macroscopic fractures at depth in crystalline rock in the Cajon Pass Scientific Drill Hole. J Geophys Res 97(B4):5181-5200

Baud P, Wong T-F, Zhu W (2014) Effects of porosity and crack density on the compressive strength of rocks. Int J Rock Mech Min Sci (in press)

Bernard M-L, Zamora M, Géraud Y, Boudon G (2007) Transport properties of pyroclastic rocks from Montagne Pelée volcano (Martinique, Lesser Antilles). J Geophys Res 112, B05205

Bibby HM, Caldwell TG, Davey F, Webb T (1995) Geophysical evidence on the structure of the Taupo Volcanic Zone and its hydrothermal circulation. J Volcanol Geotherm Res 68:29-58

Bieniawski ZT (1967) Mechanism of brittle fracture of rock part II - experimental studies. Int J Rock Mech Min Sci 4:407-423

Blake OO, Faulkner DR, Rietbrock A (2012) The effect of varying damage history in crystalline rocks on the P-and S-wave velocity under hydrostatic confining pressure. Pure Appl Geophys 170:493-505

Bloomberg S, Rissmann C, Mazot A, Oze C, Horton T, Kennedy B, Werner C, Christenson B, Pawson J (2012) Soil gas flux exploration at the Rotokawa Geothermal Field and White Island, New Zealand. In: Proceedings, Thirty Sixth Workshop on Geothermal Reservoir Engineering. Stanford University, Stanford, California. 30 January 30 to 1 February 2012

Bourbie T, Zinszner B (1985) Hydraulic and acoustic properties as a function of porosity in Fontainebleau sandstone J Geophys Res 90:11524-11532

Brace WF, Bombolakis EG (1963) A note on brittle crack growth in compression. J Geophys Res 68:3709-3713

Brace WF, Paulding B, Scholz C (1966) Dilatancy in the fracture of crystalline rocks. J Geophys Res 71:3939-3953

Brace WF, Walsh JB, Frangos WT (1968) Permeability of granite under high pressure. J Geophys Res 73:2225-2236

Byerlee JD (1978) Friction of rocks. Pure Appl Geophys 116:615-626

Chaki S, Takarli M, Agbodjan WP (2008) Influence of thermal damage on physical properties of a granite rock: porosity, permeability and ultrasonic wave evolutions. Constr Build Mater 22:1456-1461

Chang C, Zoback MD, Khaksar A (2006) Empirical relations between rock strength and physical properties in sedimentary rocks. J Pet Sci Eng 51:223-237

Cole JW (1990) Structural control and origin of volcanism in the Taupo volcanic zone, New Zealand. Bull Volcanol 52:445-459

Collar RJ, Browne PRL (1985) Hydrothermal eruptions at The Rotokawa Geothermal Field, Taupo Volcanic Zone, New Zealand. In: Proceedings of the seventh New Zealand geothermal workshop, University of Auckland. Geothermal Institute, Auckland, New Zealand. 6-8 November 1985

Costa A (2006) Permeability-porosity relationship: a re-examination of the Kozeny-Carman equation based on a fractal pore-space geometry assumption. Geophys Res Lett 33, L02318

David C, Menendez B, Darot M (1999) Influence of stress-induced and thermal cracking on physical properties and microstructure of La Peyratte granite. Int J Rock Mech Min Sci 36:433-448

Diamantis K, Gartzos E, Migiros G (2009) Study on uniaxial compressive strength, point load strength index dynamic and physical properties of serpentinites from Central Greece: test results and empirical relations. Eng Geol 108:199-207

Diederichs M, Kaiser P, Eberhardt E (2004) Damage initiation and propagation in hard rock during tunneling and the influence of near-face stress rotation. Int J Rock Mech Min Sci 41:785-812

DiPippo R (2008) Geothermal power plants: principles, applications, case studies and environmental impact, 2nd edition. Elsevier Ltd, Oxford

Doyen PM (1988) Permeability, conductivity, and pore geometry of sandstone. J Geophys Res 93:7729-7740

Eberhardt E, Stead D, Stimpson B, Read RS (1998) Identifying crack initiation and propagation thresholds in brittle rock. Can Geotech J 35:222-233

Ellis DV, Singer JM (2008) Well logging for earth scientists, 2nd edition. Springer, Dordrecht

Faoro I, Vinciguerra S, Marone C, Elsworth D, Schubnel A (2013) Linking permeability to crack density evolution in thermally stressed rocks under cyclic loading. Geophys Res Lett 40:2590-2595

Ferrero AM, Marini P (2001) Experimental studies on the mechanical behaviour of two thermal cracked marbles. Rock Mech Rock Eng 34:57-66

Finger J, Blankenship D (2010) Handbook of best practices for geothermal drilling. Sandia National Laboratories, Albuquerque

Fredrich JT, Wong T (1986) Micromechanics of thermally induced cracking in three crustal rocks. J Geophys Res 91:12743-12764

Géraud Y (1994) Variations of connected porosity and inferred permeability in a thermally cracked granite. Geophys Res Lett 21:979-982

Grant MA, Bixley PF (2011) Geothermal reservoir engineering, 2nd edition. Elsevier Science Ltd, Oxford

Guéguen Y, Palciauskas V (1994) Introduction to the physics of rocks. Princeton University Press, Princeton Guéguen Y, Schubnel A (2003) Elastic wave velocities and permeability of cracked rocks. Tectonophysics 370:163-176

Gupta H, Sukanta R (2006) Geothermal energy: an alternative resource for the 21st century. Elsevier B.V., Oxford

Hardy H (1981) Applications of acoustic emission techniques to rock and rock structures: a state of the art review. In: Drnevich V, Gray R (ed) Acoustic emission in geotechnical engineering practice. American Society for Testing and Materials, University of Michigan, Ann Arbor

Heap MJ, Faulkner DR (2008) Quantifying the evolution of static elastic properties as crystalline rock approaches failure. Int J Rock Mech Min Sci 45:564-573

Heap MJ, Vinciguerra S, Meredith PG (2009) The evolution of elastic moduli with increasing crack damage during cyclic stressing of a basalt from Mt. Etna volcano. Tectonophysics 471:153-160

Heap MJ, Lavallée Y, Laumann A, Hess K-U, Meredith PG, Dingwell DB, Huismann S, Weise F (2013) The influence of thermal-stressing (up to $1000^{\circ} \mathrm{C}$ ) on the physical, mechanical, and chemical properties of siliceous-aggregate high-strength concrete. Construct Build Mater 42:248-265 
Heap MJ, Lavallee Y, Petrakova L, Baud P, Reushcle T, Varley NR, Dingwell DB (2014) Microstructural controls on the physical and mechanical properties of edifice-forming andesites at Volcán de Colima Mexico. J Geophys Res 119:2925-2963

Heard HC, Page L (1982) Elastic moduli, thermal expansion, and inferred permeability of two granites to $350^{\circ} \mathrm{C}$ and 55 megapascals. J Geophys Res 87:9340-9348

Hedenquist JW, Mroczek EK, Giggenbach WF (1988) Geochemistry of the Rotokawa geothermal system: summary of data, interpretation and appraisal for energy development. In: Chemistry Division DSIR Technical Note 88/6.

Hole HM (2013) Geothermal drilling - keep it simple. In: Proceedings of the 35th New Zealand geothermal workshop. Rotorua, New Zealand. 17-20 November 2013

Horie T, Muto T (2010) The world's largest single cylinder geothermal power generation unit - Nga Awa Purua Geothermal Power Station, New Zealand. Geothermal Res Council Trans 34:1039-1044

Jafari A, Babadagli T (2011) Effective fracture network permeability of geothermal reservoirs. Geothermics 40:25-38

Jaya MS, Shapiro SA, Kristinsdóttir LH, Bruhn D, Milsch H, Spangenberg E (2010) Temperature dependence of seismic properties in geothermal rocks at reservoir conditions. Geothermics 39:115-123

Ju Y, Yang Y, Peng R, Mao L (2013) Effects of pore structures on static mechanical properties of sandstone. J Geotech Geoenvironmental Eng 139:1745-1755

Kahraman S (2001) Evaluation of simple methods for assessing the uniaxial compressive strength of rock. Int J Rock Mech Min Sci 38:981-994

Kahraman S, Gunaydin O, Fener M (2005) The effect of porosity on the relation between uniaxial compressive strength and point load index. Int J Rock Mech Min Sci 42:584-589

Keshavarz M, Pellet FL, Loret B (2010) Damage and changes in mechanical properties of a gabbro thermally loaded up to $1,000^{\circ} \mathrm{C}$. Pure Appl Geophys 167:1511-1523

Klinkenberg LJ (1941) The permeability of porous media to liquids and gases. Drilling and production practice. American Petroleum Institute, New York, pp 200-213

Kristinsdóttir LH, Flóvenz ÓG, Árnason K, Bruhn D, Milsch H, Spangenberg E, Kulenkampff J (2010) Electrical conductivity and P-wave velocity in rock samples from high-temperature Icelandic geothermal fields. Geothermics 39:94-105

Krupp RE, Seward TM (1987) The Rotokawa geothermal system, New Zealand; an active epithermal gold-depositing environment. Econ Geol 82:1109-1129

Lavallée Y, Benson PM, Heap MJ, Hess KU, Flaws A, Schillinger B, Meredith PG, Dingwell DB (2013) Reconstructing magma failure and the degassing network of dome-building eruptions. Geology 41:515-518

Legmann H, Sullivan P (2003) The 30 MW Rotokawa I geothermal project five years of operation. In: International geothermal conference. Reykjavik, Iceland. September 2003

Li L, Aubertin M (2003) A general relationship between porosity and uniaxial strength of engineering materials. Can J Civ Eng 30:644-658

Lim SS, Martin CD, Åkesson U (2012) In-situ stress and microcracking in granite cores with depth. Eng Geol $147-148: 1-13$

Lion M, Skoczylas F, Ledésert B (2005) Effects of heating on the hydraulic and poroelastic properties of Bourgogne limestone. Int J Rock Mech Min Sci 42:508-520

Luping T (1986) A study of the quantitative relationship between strength and pore-size distribution of porous materials. Cem Concr Res 16:87-96

Lutz SJ, Hickman S, Davatzes N, Zemach E, Drakos P, Robertson-Tait A (2010) Rock mechanical testing and petrologic analysis in support of well stimulation activities at the Desert Peak Geothermal Field, Nevada. In: Proceedings of the thirty-fifth workshop on geothermal reservoir engineering. Stanford University, Stanford, California. $1-3$ February 2010

Martin CD (1993) The strength of Massive Lac du Bonnet granite around underground openings. Dissertation, University of Manitoba

Martin CD, Chandler NA (1994) The progressive fracture of Lac du Bonnet granite. Int J Rock Mech Min Sci 31:643-659

Martínez-Martínez J, Benavente D, García-del-Cura MA (2011) Spatial attenuation: the most sensitive ultrasonic parameter for detecting petrographic features and decay processes in carbonate rocks. Eng Geol 119:84-95

Massiot C, McNamara D, Lewis B, Price L, Bignall G (2012) Statistical corrections of fracture sampling bias in boreholes from acoustic televiewer logs. In: New Zealand geothermal workshop proceedings. Auckland, New Zealand. 19-21 November 2012

Mueller S, Melnik O, Spieler O (2005) Permeability and degassing of dome lavas undergoing rapid decompression: an experimental determination. Bull Volcanol 67:526-538

Nara Y, Meredith PG, Yoneda T, Kaneko K (2011) Influence of macro-fractures and micro-fractures on permeability and elastic wave velocities in basalt at elevated pressure. Tectonophysics 503:52-59

Nara Y, Morimoto K, Hiroyoshi N, Yoneda T, Kaneko K, Benson PM (2012) Influence of relative humidity on fracture toughness of rock: implications for subcritical crack growth. Int J Solids Struct 49:2471-2481

Nicksiar M, Martin CD (2012) Evaluation of methods for determining crack initiation in compression tests on low-porosity rocks. Rock Mech Rock Eng 45:607-617

Obara Y, Sakaguchi K, Nakayama T, Sugawara K (1992) Anisotropy effect on fracture toughness of rocks. Int J Rock Mech Min Sci Geomech 30:137. Abstract

Ouchterlony F (1990) Fracture toughness testing of rock with core based specimens. Eng Fract Mech 35:351-366

Palchik V (2013) Is there a link between the type of the volumetric strain curve and elastic constants, porosity, stress and strain characteristics? Rock Mech Rock Eng 46:315-326

Palchik V, Hatzor YH (2002) Crack damage stress as a composite function of porosity and elastic matrix stiffness in dolomites and limestones. Eng Geol 63:233-245

Pereira J-M, Arson C (2013) Retention and permeability properties of damaged porous rocks. Comput Geotech 48:272-282

Pola A, Crosta G, Fusi N, Barberini V, Norini G (2012) Influence of alteration on physical properties of volcanic rocks. Tectonophysics 566-567:67-86 
Pola A, Crosta GB, Fusi N, Castellanza R (2014) General characterization of the mechanical behaviour of different volcanic rocks with respect to alteration. Eng Geol 169:1-13

Powell T (2011) Natural subsidence at the Rotokawa Geothermal Field and implications for permeability development. Geothermal Res Council Trans 35:973-976

Quinao J, Sirad-Azwar L, Clearwater J, Hoepfinger V, Le Brun M, Bardsley C (2013) Analyses and modeling of reservoir pressure changes to interpret the Rotokawa Geothermal Field response to Nga Awa Purua Power Station operation. In: Proceedings of the 38th workshop on geothermal reservoir engineering. Stanford University, Stanford, California. 11-13 February 2013

Rae A (2007) Rotokawa geology and geophysics. GNS Science consultancy report 2007/83 May 2007. GNS Science, Lower Hutt

Rae AJ, McCoy-West AJ, Ramirez LE, Alcaraz SA (2009) Geology of production well RK28. Rotokawa Geothermal Field. GNS Science consultancy report 2009/253 September 2009. GNS Science, Lower Hutt

Rae AJ, McCoy-West AJ, Ramirez LE, McNamara D (2010) Geology of production wells RK30L1 and RK30L2, Rotokawa Geothermal Field. GNS Science consultancy report 2010/02 January 2010. GNS Science, Lower Hutt

Rajabzadeh MA, Moosavinasab Z, Rakhshandehroo G (2011) Effects of rock classes and porosity on the relation between uniaxial compressive strength and some rock properties for carbonate rocks. Rock Mech Rock Eng 45:113-122

Ramirez LE, Hitchcock D (2010) Geology of production well RK27L2, Rotokawa Geothermal Field, GNS Science Consultancy Report 2010/100 April 2010. GNS Science, Lower Hutt

Reuschlé T, Gbaquidi Haore S, Darot M (2006) The effect of heating on the microstructural evolution of La Peyratte granite deduced from acoustic velocity measurements. Earth Planet Sci Lett 243:692-700

Richter D, Simmons G (1977) Microcracks in crustal igneous rocks: microscopy. In: Heacock JG, Keller GV, Oliver JE, Simmons G (ed) The earth's crust. American Geophysical Union, Washington, DC

Rowland JV, Sibson RH (2004) Structural controls on hydrothermal flow in a segmented rift system, Taupo Volcanic Zone, New Zealand. Geofluids 4:259-283

Rowland JV, Wilson CJN, Gravley DM (2010) Spatial and temporal variations in magma-assisted rifting, Taupo Volcanic Zone, New Zealand. J Volcanol Geotherm Res 190:89-108

Rust AC, Manga M, Cashman KV (2003) Determining flow type, shear rate and shear stress in magmas from bubble shapes and orientations. J Volcanol Geotherm Res 122:111-132

Rutter EH (1986) On the nomenclature of mode of failure transitions in rocks. Tectonophysics 122:381-387

Saar MO, Manga M (1999) Permeability-porosity relationship in vesicular basalts. Geophys Res Lett 26:111-114

Schöpfer MPJ, Abe S, Childs C, Walsh JJ (2009) The impact of porosity and crack density on the elasticity, strength and friction of cohesive granular materials: insights from DEM modelling. Int J Rock Mech Min Sci 46:250-261

Sewell SM, Cumming WB, Azwar L, Bardsley C (2012) Integrated MT and natural state temperature interpretation for a conceptual model supporting reservoir numerical modelling and well targeting at the Rotokawa Geothermal Field, New Zealand. In: Proceedings of the thirty-seventh workshop on geothermal reservoir engineering. Stanford University, Stanford California. 30 January to 1 February 2012

Sewell SM, Cumming W, Bardsley CJ, Winick J, Quinao J, Wallis IC, Sherburn S, Bourguignon S, Bannister S (2013) Interpretation of microearthquakes at the Rotokawa Geothermal Field, 2008 to 2012. In: Proceedings of the 35th New Zealand geothermal workshop. Rotorua, New Zealand. 17-20 November 2013

Sherburn S, Bourguignon S, Bannister S, Sewell S, Cumming B, Bardsley C, Quinao J, Wallis I (2013) Microseismicity at Rotokawa Geothermal Field, 2008 to 2012. In: Proceedings of the 35th New Zealand geothermal workshop. Rotorua, New Zealand. 17-20 November 2013

Siega C, Grant M, Powell T (2009) Enhancing injection well performance by cold water stimulation in Rotokawa and Kawerau geothermal field. In: Proceedings of PNOC-EDC conference. Manila, Philippines. 27-28 September 2009

Smith R, Sammonds PR, Kilburn CRJ (2009) Fracturing of volcanic systems: experimental insights into pre-eruptive conditions. Earth Planet Sci Lett 280:211-219

Sousa LMO, Suárez del Río LM, Calleja L, Ruiz de Argandoña VG, Rey AR (2005) Influence of microfractures and porosity on the physico-mechanical properties and weathering of ornamental granites. Eng Geol 77:153-168

Stanchits S, Vinciguerra S, Dresen G (2006) Ultrasonic velocities, acoustic emission characteristics and crack damage of basalt and granite. Pure Appl Geophys 163:975-994

Stimac JA, Powell TS, Golla GU (2004) Porosity and permeability of the Tiwi geothermal field, Philippines, based on continuous and spot core measurements. Geothermics 33:87-107

Stimac J, Nordquist G, Suminar A, Sirad-Azwar L (2008) An overview of the Awibengkok geothermal system, Indonesia. Geothermics 37:300-331

Takarli M, Prince W, Siddique R (2008) Damage in granite under heating/cooling cycles and water freeze thaw condition. Int J Rock Mech Min Sci 45:1164-1175

Tugrul A, Gurpinar O (1997) The effect of chemical weathering on the engineering properties of Eocene basalts in northeastern Turkey. Environ Eng Geosci 3:225-234

Tutluoglu L, Keles C (2011) Mode I fracture toughness determination with straight notched disk bending method. Int J Rock Mech Min Sci 48:1248-1261

Ulusay R, Hudson J (2007) The complete ISRM suggested methods for rock characterization, testing and monitoring: 1974-2006. Elsevier, Antalya, Turkey

Underwood EE (1970) Quantitative stereology for microstructural analysis. In: Underwood EE (ed) Quantitative stereology. Addison-Wesley, Reading, Massachusetts

Vernik L, Bruno M, Bovberg C (1993) Empirical relations between compressive strength and porosity of siliciclastic rocks. Int J Rock Mech Min Sci Geomech 30:677-680. Abstract

Vinciguerra S, Trovato C, Meredith P, Benson P (2005) Relating seismic velocities, thermal cracking and permeability in Mt. Etna and Iceland basalts. Int J Rock Mech Min Sci 42:900-910

Wallis I, McCormick S, Sewell S, Boseley C (2009) Formation assessment in geothermal using wireline tools - application and early results from the Ngatamariki Geothermal Field, New Zealand. In: Proceedings of the New Zealand Geothermal Workshop. Rotorua, New Zealand. 16-18 November 2009 
Walsh JB (1965a) The effect of cracks on the compressibility of rock. J Geophys Res 70:381-389

Walsh JB (1965b) The effect of cracks in rocks on Poisson's ratio. J Geophys Res 70:5249-5257

Wang HF, Bonner BP, Carlson SR, Kowallis BJ, Heard HC (1989) Thermal stress cracking in granite. J Geophys Res 94:1745-1758

Watanabe T, Shimizu Y, Noguchi S, Nakada S (2008) Permeability measurements on rock samples from Unzen Scientific Drilling Project Drill Hole 4 (USDP-4). J Volcanol Geotherm Res 175:82-90

Wilson CJN, Houghton BF, Mcwilliams MO, Lanphere MA, Weaver SD, Briggs RM (1995) Volcanic and structural evolution of Taupo Volcanic Zone, New Zealand: a review. J Volcanol Geotherm Res 68:1-28

Wong TF, Baud P (2012) The brittle-ductile transition in porous rock: a review. J Struct Geol 44:25-53

Wu XY, Baud P, Wong TF (2000) Micromechanics of compressive failure and spatial evolution of anisotropic damage in Darley Dale sandstone. Int J Rock Mech Min Sci 37:143-160

doi:10.1186/s40517-014-0010-4

Cite this article as: Siratovich et al:: Physical property relationships of the Rotokawa Andesite, a significant geothermal reservoir rock in the Taupo Volcanic Zone, New Zealand. Geothermal Energy 2014 2:10.

Submit your manuscript to a SpringerOpen ${ }^{\circ}$ journal and benefit from:

- Convenient online submission

- Rigorous peer review

- Immediate publication on acceptance

- Open access: articles freely available online

- High visibility within the field

- Retaining the copyright to your article 